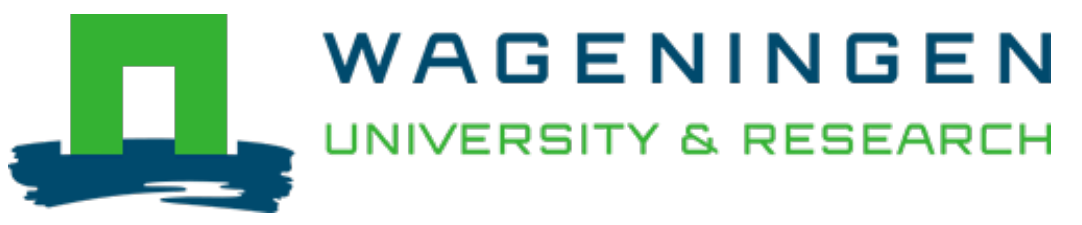

\title{
Long-term physiological and growth responses of Himalayan fir to environmental change are mediated by mean climate
}

\author{
Global Change Biology \\ Panthi, Shankar; Fan, Ze Xin; Sleen, Peter; Zuidema, Pieter A. \\ https://doi.org/10.1111/gcb.14910
}

This publication is made publicly available in the institutional repository of Wageningen University and Research, under the terms of article $25 \mathrm{fa}$ of the Dutch Copyright Act, also known as the Amendment Taverne. This has been done with explicit consent by the author.

Article 25 fa states that the author of a short scientific work funded either wholly or partially by Dutch public funds is entitled to make that work publicly available for no consideration following a reasonable period of time after the work was first published, provided that clear reference is made to the source of the first publication of the work.

This publication is distributed under The Association of Universities in the Netherlands (VSNU) 'Article $25 \mathrm{fa}$ implementation' project. In this project research outputs of researchers employed by Dutch Universities that comply with the legal requirements of Article $25 \mathrm{fa}$ of the Dutch Copyright Act are distributed online and free of cost or other barriers in institutional repositories. Research outputs are distributed six months after their first online publication in the original published version and with proper attribution to the source of the original publication.

You are permitted to download and use the publication for personal purposes. All rights remain with the author(s) and / or copyright owner(s) of this work. Any use of the publication or parts of it other than authorised under article $25 \mathrm{fa}$ of the Dutch Copyright act is prohibited. Wageningen University \& Research and the author(s) of this publication shall not be held responsible or liable for any damages resulting from your (re)use of this publication.

For questions regarding the public availability of this publication please contact openscience.library@wur.nl 


\title{
Long-term physiological and growth responses of Himalayan fir to environmental change are mediated by mean climate
}

\author{
Shankar Panthi ${ }^{1,2}$ (i) | Ze-Xin Fan ${ }^{1,2,3}$ (D) | Peter van der Sleen ${ }^{4} \mid$ Pieter A. Zuidema $^{5}$ (D)
}

${ }^{1}$ CAS Key Laboratory of Tropical Forest Ecology, Chinese Academy of Sciences, Mengla, Yunnan, China

${ }^{2}$ Center for Plant Ecology, Chinese Academy of Sciences, Xishuangbanna, China

${ }^{3}$ Ailaoshan Station of Subtropical Forest Ecosystem Studies, Chinese Academy of Sciences, Jingdong, Yunnan, China

${ }^{4}$ Department of Wetland Ecology, Karlsruhe Institute of Technology, Rastatt, Germany

${ }^{5}$ Forest Ecology \& Forest Management Group, Wageningen University, Wageningen, The Netherlands

\section{Correspondence}

Ze-Xin Fan, CAS Key Laboratory of Tropical Forest Ecology, Xishuangbanna Tropical Botanical Garden, Chinese Academy of Sciences, Menglun, Mengla, Yunnan 666303, China.

Email: fanzexin@xtbg.org.cn

Funding information

National Key Research Development Program of China, Grant/Award Number: 2016YFC0502105; National Natural Science Foundation of China, Grant/Award Number: 31770533 and 3186113307 ; Marie Curie Individual Fellowship, Grant/Award Number: 746181; The CAS President's International Fellowship Initiative, Grant/Award Number: 2019PC0104 and 2018VCA0037; CAS 135 Program, Grant/Award Number: 2017XTBG-T01

\begin{abstract}
High-elevation forests are experiencing high rates of warming, in combination with $\mathrm{CO}_{2}$ rise and (sometimes) drying trends. In these montane systems, the effects of environmental changes on tree growth are also modified by elevation itself, thus complicating our ability to predict effects of future climate change. Tree-ring analysis along an elevation gradient allows quantifying effects of gradual and annual environmental changes. Here, we study long-term physiological (ratio of internal to ambient $\mathrm{CO}_{2}$, i.e., $\mathrm{C}_{\mathrm{i}} / \mathrm{C}_{\mathrm{a}}$ and intrinsic water-use efficiency, iWUE) and growth responses (treering width) of Himalayan fir (Abies spectabilis) trees in response to warming, drying, and $\mathrm{CO}_{2}$ rise. Our study was conducted along elevational gradients in a dry and a wet region in the central Himalaya. We combined dendrochronology and stable carbon isotopes $\left({ }^{13} \mathrm{C}\right)$ to quantify long-term trends in $C_{i} / C_{a}$ ratio and iWUE $\left({ }^{13} C\right.$-derived), growth (mixed-effects models), and evaluate climate sensitivity (correlations). We found that iWUE increased over time at all elevations, with stronger increase in the dry region. Climate-growth relations showed growth-limiting effects of spring moisture (dry region) and summer temperature (wet region), and negative effects of temperature (dry region). We found negative growth trends at lower elevations (dry and wet regions), suggesting that continental-scale warming and regional drying reduced tree growth. This interpretation is supported by $\delta^{13} \mathrm{C}$-derived long-term physiological responses, which are consistent with responses to reduced moisture and increased vapor pressure deficit. At high elevations (wet region), we found positive growth trends, suggesting that warming has favored tree growth in regions where temperature most strongly limits growth. At lower elevations (dry and wet regions), the positive effects of $\mathrm{CO}_{2}$ rise did not mitigate the negative effects of warming and drying on tree growth. Our results raise concerns on the productivity of Himalayan fir forests at low and middle $(<3,300 \mathrm{~m})$ elevations as climate change progresses.
\end{abstract}

\section{KEYWORDS}

central Himalaya, climate change, elevation gradients, high-elevation forests, Himalayan fir (Abies spectabilis), intrinsic water-use efficiency (iWUE), long-term growth trends, tree rings

\section{1 | INTRODUCTION}

Forests play a crucial role in the global cycles of water and carbon (Keenan et al., 2013). While covering approximately one-third of the
Earth's land surface, forests contribute to about $50 \%$ of the terrestrial net primary productivity, store roughly $45 \%$ of total terrestrial carbon, and account for $80 \%-90 \%$ of all plant carbon (Bonan, 2008). As forests play a major role in atmospheric stabilization (Bonan, 2008; 
Le Quéré et al., 2018), it is important to understand how long-term tree physiology and growth will respond to global changes (Charney et al., 2016; Silva et al., 2016; Zuidema et al., 2013).

Forest ecosystems are faced with a variety of climatic and atmospheric changes: rising temperature, warming-induced atmospheric drought, shifting rainfall patterns, and elevated atmospheric $\left[\mathrm{CO}_{2}\right]$. These changes will influence tree physiology, growth, and forest productivity in complex and interactive ways (Bonan, 2008; Reed, Ballantyne, Cooper, \& Sala, 2018). One of the challenges in studies of global change effects on forests is to disentangle effects of these changing drivers. The expected effect of elevated $\left[\mathrm{CO}_{2}\right]$ on tree photosynthesis and carbon availability (Huang, Bergeron, Denneler, Berninger, \& Tardif, 2007) may differ across environmental conditions and warming (Lévesque, Siegwolf, Saurer, Eilmann, \& Rigling, 2014; Lindner et al., 2010; Sarris, Siegwolf, \& Körner, 2013). For instance, a substantial number of studies reported declining long-term tree growth and productivity (Barber, Juday, \& Finney, 2000; Giguère-Croteau et al., 2019; Girardin, Bouriaud, et al., 2016; Girardin, Hogg, et al., 2016; Lévesque et al., 2014; Nock et al., 2011; Silva \& Anand, 2013) due to regional drought or warming-induced drought (Liang, Leuschner, Dulamsuren, Wagner, \& Hauck, 2016; Linares \& Camarero, 2012; Peñuelas, Canadell, \& Ogaya, 2011; Peters et al., 2018; Rahman, Islam, Gebrekirstos, \& Bräuning, 2019). For montane and boreal forests, no growth enhancement related to elevated $\mathrm{CO}_{2}$ was found (Dawes et al., 2010; Hättenschwiler, Miglietta, Raschi, \& Korner, 1997; Klein et al., 2016; Sigurdsson, Medhurst, Wallin, Eggertsson, \& Linder, 2013). In contrast, tree growth in some high-elevation forests has accelerated due to warming and atmospheric $\left[\mathrm{CO}_{2}\right]$ rise in regions where temperature is the prevailing growth-limiting factor (Huang et al., 2017; Lindner et al., 2010; Qi, Liu, Wu, \& Hao, 2015; Salzer, Hughes, Bunn, \& Kipfmueller, 2009; Silva et al., 2016).

High mountainous forest ecosystems present unique opportunities to study the interactive effects of climate and atmospheric change (Körner, 2007, 2012; Mountain Research Initiative EDW Working Group, 2015) because they are often characterized by strong gradients in temperature and rainfall and their interactions at relatively short distances (Barry, 2008). Such environmental gradients exist in high-elevation forests in the Himalayas. The complex topo-geography also creates strong seasonality (ca. 60\%-80\% of total annual precipitation falls during summer) in the central Himalayas (Böhner, Miehe, Miehe, \& Nagy, 2015), which determines growth patterns and productivity of Himalayan montane forests. In addition, the Himalayas are experiencing higher rates of temperature change $\left(0.6^{\circ} \mathrm{C}\right.$ per decade) than surrounding lowlands and the global average (IPCC, 2013). At the same time, regional drying trends due to decreasing seasonal precipitations and increasing drought/ aridity were observed during the past decades in the central Himalayas (Gaire, Bhuju, et al., 2017; Panthi, Bräuning, Zhou, \& Fan, 2017; Sano, Ramesh, Sheshshayee, \& Sukumar, 2012; Xu et al., 2018). Thus, it is likely that moisture availability has importantly driven response of Himalayan montane forests to past warming (Liang, Dawadi, Pederson, \& Eckstein, 2014; Sigdel et al., 2018).

\section{Highlights}

- Long-term tree physiological and growth responses of Himalayan fir to climatic and atmospheric changes were mediated by mean climate (temperature and rainfall).

- Intrinsic water-use efficiency has increased during the past century across elevations and in both dry and wet regions, with stronger responses in dry region.

- Tree radial growth was reduced in years with higher (spring) temperature and increased in years with higher precipitation and moisture availability in the dry region, while (summer) temperature had a positive effect in the wet region.

- Long-term trends in tree growth were negative at low to middle elevations in both dry and wet regions, and positive at high elevations in the wet region.

Himalayan forests are complex ecosystems due to their biogeographical history, the topographic variety, and the strong climatic gradients along elevational gradients (Böhner et al., 2015; Miehe et al., 2015). Bioclimatic conditions drive the presence of various vegetation types, mainly montane forests at high elevations in the Himalayas (Miehe et al., 2015). One of the dominant tree species in montane forests is Abies spectabilis (D. Don) Spach (Himalayan fir), which is found along a wide elevational range (Fu, Li, \& Elias, 1999; Miehe et al., 2015). Tree-ring studies have revealed that tree radial growth of Himalayan fir in dry regions is primarily limited by spring moisture availability (Gaire, Bhuju, et al., 2017; Kharal et al., 2017; Sigdel et al., 2018). At higher elevations in wet regions, tree growth is sensitive to growing season temperature (Gaire, Koirala, Bhuju, \& Carrer, 2017; Shrestha, Chhetri, \& Bista, 2017). Dendroecological studies of Himalayan montane forests along elevation gradients are scant (Kharal et al., 2017; Shrestha et al., 2017), and were all restricted to reporting growth-climate response in a specific region. Yet, such studies are of limited use to estimate effects of future environmental changes (warming, drying $\mathrm{CO}_{2}$ rise) on Himalayan fir. We therefore conducted a comprehensive dendroecological study on Himalayan fir which we sampled along elevational gradients and in a wet and dry region, to understand how mean climatic conditions (temperature, rainfall) drive climate-growth relations, physiological trends (intrinsic water-use efficiency [iWUE]), and long-term growth trends. A better understanding on these long-term physiological and growth responses of Himalayan fir to past environmental changes may provide important insights on the vulnerability of Himalayan montane forests to future environmental changes.

In this study, we aim to evaluate and interpret long-term trends in physiological and growth responses of Himalayan fir (A. spectabilis) to climatic and atmospheric changes. We measured tree-ring width (TRW) and stable carbon isotope $\left(\delta^{13} \mathrm{C}\right)$ in two regions that differ strongly in rainfall. Furthermore, in each region, we sampled trees along a wide elevational (temperature) gradient. We hypothesized 
that trees growing on wet region and at higher elevations are more sensitive to temperature, whereas trees growing on dry region and lower elevation belts are more limited by moisture availability (Körner, 2015). We expected that trees growing at temperaturelimited ecosystems (higher elevation belts in wet region) will benefit from warming, whereas trees growing in moisture-limited ecosystems (dry region and lower elevation belts) will encounter drought stress, possibly resulting in reduced growth. In the latter case, $\mathrm{CO}_{2}$ rise may have (partially) compensated for the negative effect of warming in these regions.

We addressed the following questions: (a) What are the longterm physiological responses (ratio of internal to ambient $\mathrm{CO}_{2}$, i.e., $\mathrm{C}_{\mathrm{i}} / \mathrm{C}_{\mathrm{a}}$ and iWUE) to $\mathrm{CO}_{2}$ rise and trends in climate (precipitation, temperature, and vapor pressure deficit [VPD]) trends? Do these responses depend on mean climatic conditions of the study area (i.e., dry vs. wet regions and low to high elevations)? (b) What is the sensitivity of annual tree growth to temperature and moisture availability, and how does this vary between regions (dry vs. wet) and along elevation (low to high)? (c) What is the direction and magnitude of long-term growth trends, and how these trends be explained by $\mathrm{CO}_{2}$ rise and climatic changes (warming and drying trends)?

\section{2 | MATERIALS AND METHODS}

\section{1 | Study area}

The study was conducted in high-elevation forests of the central Himalaya, Nepal. Study regions are located in high-elevation nature reserves at Rara National Park in western Nepal (the dry region), and Gaurishankar Conservation Area in eastern Nepal (the wet region; Figure 1). Himalayan Mountains encompasses a transition of both maritime and continental climate causing warm and wet summers, and cold and dry winters (Böhner et al., 2015). Furthermore, the east-west running massif crestlines of the Himalayas and the north-south oriented, deeply incised river gorges create a complex topography and a variety of climatic conditions along elevation gradients. The topographic complexity and varied climatic conditions of the Himalayas contribute to diverse vegetation types, making this one of plant biodiversity hotspots in the world (Myers, Mittermeier, Mittermeier, Fonseca, \& Kent, 2000).

Rara National Park is located in the trans-Himalayan rain shadow zone in the northwestern part of Nepal and characterized by dry conditions. The vegetation is characterized by rich montane coniferous forest of Himalayan fir (A. spectabilis), Blue pine (Pinus wallichiana), and Himalayan spruce (Picea smithiana) along with Oak (Quercus semecarpifolia), Birch (Betula utilis). A. spectabilis is dominant above $3,300 \mathrm{~m}$ on the northern slopes of mountains, and forms a continuous upper montane forest from $2,800 \mathrm{~m}$ up to alpine treeline ecotone at 3,800 m a.s.I. (DNPWC, 2015; Panthi, 2017). Gaurishankar Conservation Area is located in the northeastern part of central Nepal and characterized by humid conditions due to high summer rainfall in this region, and the vegetation is characterized by deciduous, mixed broad-leaved and evergreen montane coniferous forests. Himalayan fir forms moist and humid upper montane forests continuously from 2,800 m to upper treeline (3,900-4,000 m; Miehe et al., 2015).

Meteorological records from Jumla station $\left(29.27^{\circ} \mathrm{N}, 82.18^{\circ} \mathrm{E}\right.$, 2,366 $\mathrm{m}$ a.s.l., dry region, west Nepal) show a total annual precipitation of $829 \mathrm{~mm}$ from year to year. About $66 \%$ of the total annual precipitation falls during the summer monsoon (unimodal) from June to September. Spring (March-May) precipitation accounts 19\% of total annual precipitation. The average annual maximum, mean, and minimum temperatures at Jumla are $21.30,12.71$, and $4.77^{\circ} \mathrm{C}$, respectively (Figure 1). The total annual precipitation at Jiri station $\left(27.63^{\circ} \mathrm{N}, 86.23^{\circ} \mathrm{E}, 2003 \mathrm{~m}\right.$ a.s.l., wet region, east Nepal) is $2,340 \mathrm{~mm}$ (year-year), with about $80 \%$ of the total annual precipitation falling during the summer monsoon season (June-September), while spring (March-May) precipitation accounts for only $\sim 13 \%$ of the total annual precipitation. The average annual maximum, mean, and minimum temperatures at Jiri are $20.24,14.23$, and $8.22^{\circ} \mathrm{C}$, respectively (Figure 1). Significant warming trends have been observed in mean
FIGURE 1 Map showing topography, meteorological stations, Climatic Research Unit (CRU) grid cells, and sampling sites of Himalayan fir in two regions contrasting in rainfall in the central Himalaya, Nepal. DRY, dry region (Rara National Park, west Nepal); and WET, wet region (Gaurishankar Conservation Area, east Nepal). Insets show monthly variations of temperatures (circle lines; red: maximum temperature; black: mean temperature; and blue: minimum temperature) and precipitation (gray bars) at Jumla (upper left, dry region) and Jiri station (upper right, wet region)

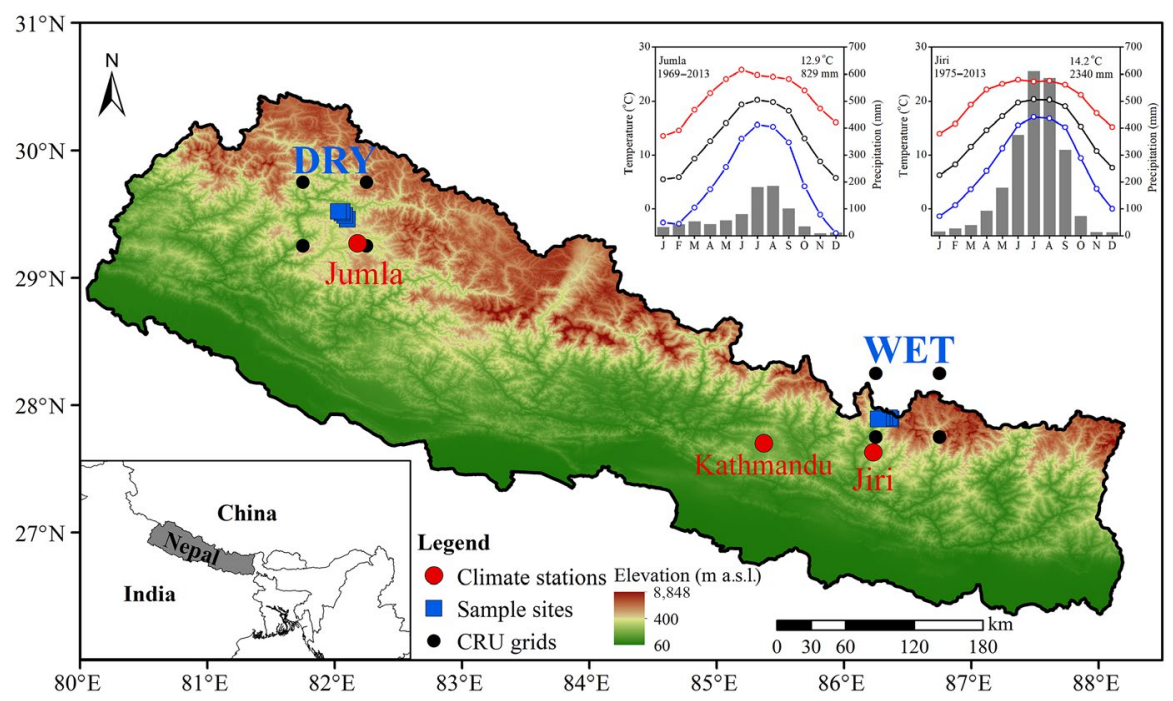


annual temperatures (MATs) over the past decades at both Jumla $\left(0.26^{\circ} \mathrm{C}\right.$ per decade) and Jiri $\left(0.162^{\circ} \mathrm{C}\right.$ per decade) station (Figure S1). In addition, an even stronger warming trend was present in maximum annual temperature at both Jumla $\left(0.4^{\circ} \mathrm{C}\right.$ per decade) and Jiri $\left(0.512^{\circ} \mathrm{C}\right.$ per decade) station (Figure S1). Meanwhile, no significant changes have been observed for annual precipitation at both Jumla and Jiri station (Figure S1d). Significantly increasing trends were found for VPD at both Jumla and Jiri station (Figure S1e). Treering-based reconstructions of drought indices indicate long-term moisture stress in the dry region during spring (Panthi et al., 2017) and summer (Sano et al., 2012) in the past century (Figure S1f).

\section{2 | Tree-ring data}

\subsection{1 | Study species}

Himalayanfir(A.spectabilis) isakeystonespeciesinthehigh-elevation Himalayan montane forests. The species is native in the central and western Himalayas and has a wide distribution from Afghanistan $\left(70^{\circ} \mathrm{E}\right)$ to eastern Nepal $\left(88^{\circ} \mathrm{E}\right)$ including northwest India and north Pakistan (Fu et al., 1999; Miehe et al., 2015). Himalayan fir has extensive elevational distribution range from 2,800 $\mathrm{m}$ a.s.l. to the upper treeline. The species is canopy dominant and mostly forms pure stands of closed forest belts. Himalayan fir is cold tolerant and adapted to a cool and humid climate, with humid conditions being driven by the fogs and convective cloud cover. The species grows on the deeply weathered podzols soil mostly on the north-facing slopes of the Himalayan Mountains (Miehe et al., 2015).

\subsection{2 | Tree-ring sampling}

Tree-ring increment cores (wood cores) of Himalayan firs were taken along an elevation gradient in the dry (west Nepal) and wet (east Nepal) region. In both regions, tree-ring increment cores were collected from mature forest stands without signs of recent (anthropogenic) disturbances at five elevational belts, that is, 2,800, 3,000, 3,300, 3,600 m, and upper forest line/treeline $(3,800 \mathrm{~m}$ in dry region and $3,900 \mathrm{~m}$ in wet region; Table 1). Two increment cores of $5.15 \mathrm{~mm}$ diameter per tree were extracted at breast height (DBH). At each elevation belts, we sampled all healthy living trees with $\mathrm{DBH} \geq 10 \mathrm{~cm}$ from two $400 \mathrm{~m}^{2}$ $(20 \mathrm{~m} \times 20 \mathrm{~m})$ plots to collect increment cores following the population structure (Figure S2). At least 60 trees were sampled at each elevation belt. In case insufficient trees were available within the sampling plots, increment cores were also collected outside the plots at the same elevation. We ensured sampling equal proportions of small and large trees at each elevation (Figure S2) to avoid the "Big tree" sampling bias that can induce spurious positive long-term growth trends (Brienen, Gloor, \& Zuidema, 2012). Seedlings (diameter at base $\leq 1 \mathrm{~cm}$ ) and saplings $(1 \mathrm{~cm}<$ diameter at base $\leq 5 \mathrm{~cm}$ ) were counted for four $5 \times 5 \mathrm{~m}^{2}$ subplots and small trees $(\mathrm{DBH} \leq 10 \mathrm{~cm})$ were counted for the

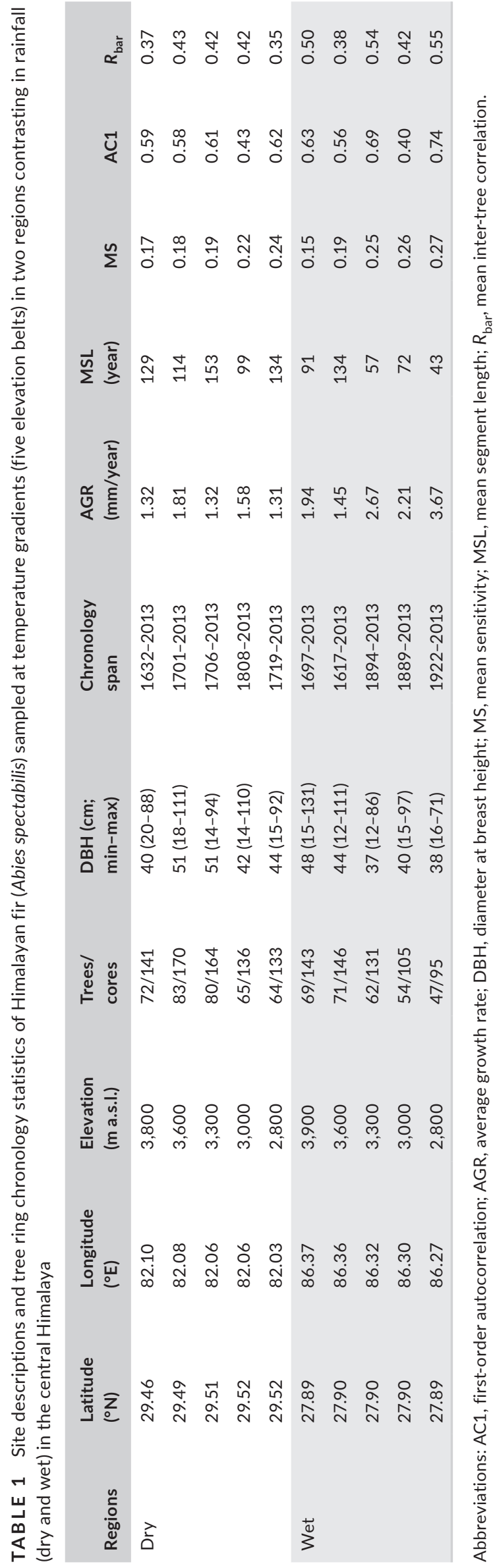


whole plot in each of the $400 \mathrm{~m}^{2}$ plot in each elevational belt. All the studied plots showed continuous recruitment with abundant seedling, sampling, and small trees (Figure S3). Therefore, we do not expect sampling bias due to recent recruitment failure for our studied species, which induce spurious negative growth trends (Brienen, Gloor, \& Ziv, 2017). Tree height and DBH of each sampled trees and geographical coordinates (latitude, longitude, and altitude), slope and aspect of each sampled plots were recorded.

\subsection{3 | Tree-ring measurement, standardization, and chronology development}

We used standard dendrochronological techniques for sample preparation, ring-width measurement, and cross-dating (Stokes \& Smiley, 1996). Increment cores were air-dried, and then, the wood surfaces were smoothed by sanding papers with consecutively finer grits until ring boundaries were clearly visible. TRWs were measured to a precision of $0.001 \mathrm{~mm}$ using LINTAB measuring device (LINTAB $^{\text {TM }}$ 6; Rinntech). Tree-ring measurements were cross-dated by visual curve matching and statistical tests (sign test and $t$ test) using the software TSAP-Win (Rinn, 2003). A total of 1,364 cores from 667 trees were cross-dated (Table 1 ), while poorly dated, heavily fragmented, and rotten cores were excluded from further analyses. For each elevation belt per region, the raw ring-width measurements were standardized to ring-width indices, and a chronology was calculated by taking the mean of all detrended series. At the time of sampling (June 2014), ring formation had already commenced in the dry region, but this was not the case in the wet region (Appendix S1). We therefore used tree-ring data up to 2013 in both regions for further analyses.

We calculated basal area increment (BAI) from the TRW, assuming the increment of each ring is uniform in a circular cross section of the tree (Peters, Groenendijk, Vlam, \& Zuidema, 2015; Salzer et al., 2009; Silva \& Anand, 2013). The raw measurements of ring-width series were converted into BAI based on the distance between the innermost measured ring and the pith of the tree by using the package dpIR (Bunn, 2008) in R (R Core Team, 2018). The raw ring-width series of each tree were converted into $\mathrm{BAI}\left(\mathrm{cm}^{2}\right.$ per year) using the relation:

$$
\mathrm{BAI}=\pi\left(R_{t}^{2}-R_{t-1}^{2}\right),
$$

where $R$ is the tree radial radius and $t$ is the year of tree-ring formation.

\subsection{4 | Growth trend analyses: Size class isolation}

To compare the long-term tree growth in time at a constant ontogenetic stage, growth trends were evaluated at fixed diameters (Peters et al., 2015; van der Sleen et al., 2015), using size-class isolation ( $\mathrm{SCl}$; Peters et al., 2015). We calculated 5 year average tree-ring width $\left(\mathrm{TRW}_{\mathrm{sci}}\right)$ and basal area increment $\left(\mathrm{BAI}_{\mathrm{sci}}\right)$ as in five fixed diameters:
$10,15,20,25$, and $30 \mathrm{~cm}$. To this end, we included the central ring (the ring at fixed diameter) and the two rings formed before and after the central ring (the average of $n-2, n-1, n, n+1$, and $n+2$, where $n$ is the central ring of fixed diameter; van der Sleen et al., 2015). The $\mathrm{SCl}$ removes the year-to-year variation in tree growth due to yearto-year climate variability. The $\mathrm{SCl}$ depends on large sample sizes but fully accounts for potential trends in tree age/size, and thus is the most reliable method for growth trends detection (Peters et al., 2015).

\subsection{Stable carbon isotope $\left(\delta^{13} \mathrm{C}\right)$ data and intrinsic water-use efficiency}

We selected cores from four representative canopy trees at three elevation belts in each study region for stable isotopes $\left(\delta^{13} \mathrm{C}\right)$ measurements. We analyzed stable carbon isotope $\left(\delta^{13} \mathrm{C}\right)$ for the period 1900-2013. During this period, sampled trees were $\geq 20 \mathrm{~cm} \mathrm{DBH}$, and therefore in the canopy or subcanopy of the typical low-stature forests in the region where the minimum size of tree to reach the canopy was $27 \mathrm{~cm}$ (wet region) and $35 \mathrm{~cm}$ (dry region). Thus, we did not standardize the diameter of our isotope samples (van der Sleen et al., 2015); our samples are not strongly influenced by ontogenetic trends in iWUE (Brienen, Gloor, Clerici, et al., 2017). In addition, we included tree size (DBH) in the statistical analyses (see below).

Wood material from annual rings was cut into small pieces of ca. $0.05 \mathrm{~mm}$ in size using a razor blade, and weighted before chemical treatment of extraction (Panthi, 2017). A multiple samples batch isolation system (Wieloch, Helle, Heinrich, Voigt, \& Schyma, 2011) was applied to extract highly purified $\alpha$-cellulose from wood samples of annual rings. The freeze-dried $\alpha$-cellulose samples were weighted into a tin $(\mathrm{Sn})$ capsule and stable carbon isotopes $\left(\delta^{13} \mathrm{C}\right)$ were determined by using mass spectrometry via Elemental analyzer (IsoPrime100; Isoprime) linked to the isotope ratio mass spectrometer at the Central Laboratory of Xishuangbanna Tropical Botanical Garden.

We calibrated the isotopic ratios as the relative deviation with reference materials (McCarroll \& Loader, 2004). The relative deviations of $\delta^{13} \mathrm{C}(\% \circ)$ were calculated as,

$$
\delta^{13} \mathrm{C}(\% \circ)=\left[\left({ }^{13} \mathrm{C} /{ }^{12} \mathrm{C}\right)_{\text {sample }} /\left({ }^{13} \mathrm{C} /{ }^{12} \mathrm{C}\right)_{\text {standard }}-1\right] \times 1,000,
$$

where $\left({ }^{13} \mathrm{C} /{ }^{12} \mathrm{C}\right)_{\text {sample }}$ and $\left({ }^{13} \mathrm{C} /{ }^{12} \mathrm{C}\right)_{\text {standard }}$ are the heavy to light carbon isotope ratios in the cellulose sample and the International standard (Vienna Pee Dee Belemnite).

Using the atmospheric and tree-ring $\delta^{13} \mathrm{C}$, the carbon isotopic discrimination $\left(\triangle^{13} \mathrm{C}, \%\right.$ o) occurring in trees was calculated as,

$$
\Delta^{13} \mathrm{C}=\left(\delta^{13} C_{\text {atm }}-\delta^{13} C_{\text {tree }}\right) /\left(1,000+\delta^{13} C_{\text {tree }}\right) \times 1,000,
$$

where $\delta^{13} C_{a t m}$ and $\delta^{13} C_{\text {tree }}$ are the fractional difference in isotopic composition $\left({ }^{13} \mathrm{C} / \mathrm{C}^{12}\right)$ in atmospheric $\mathrm{CO}_{2}$ and that of tree-ring cellulose (Farquhar, O'Leary, \& Berry, 1982). 
Carbon isotopic discrimination $\left(\Delta^{13} \mathrm{C}\right)$ is related to intercellular $\mathrm{CO}_{2}\left(\mathrm{C}_{\mathrm{i}}\right)$ and ambient $\mathrm{CO}_{2}\left(\mathrm{C}_{\mathrm{a}}\right)$ concentration as,

$$
\Delta^{13} \mathrm{C}=a+(b-a)\left(\mathrm{C}_{\mathrm{i}} / \mathrm{C}_{\mathrm{a}}\right)
$$

where $a$ is fractionation factor during intercellular diffusion (-4.4\%o), and $b$ is fractionation factor during carboxylation (-27\%; Farquhar et al., 1982).

The ratio of $\mathrm{C}_{\mathrm{i}}$ and $\mathrm{C}_{\mathrm{a}}$ was determined following Francey and Farquhar (1982) and Farquhar et al. (1982) as,

$$
\mathrm{C}_{\mathrm{i}} / \mathrm{C}_{\mathrm{a}}=\left[\left(\delta^{13} \mathrm{C}_{\text {tree }}-\delta^{13} \mathrm{C}_{\mathrm{atm}}+a\right) /(a-b)\right]
$$

We compiled the historic $\delta^{13} \mathrm{C}_{\mathrm{atm}}$ from McCarroll and Loader (2004) up to year 2004 (http://www.esrl.noaa.gov/gmd/), and after that was derived from Keeling, Piper, Bollenbacher, and Walker (2009; http:// scrippsco2.ucsd.edu/). Using the $C_{i}$ and $C_{a}$ values, we calculated iWUE as,

$$
\text { iWUE }=\left(C_{a}-C_{i}\right) / 1.6
$$

\subsection{Climate data}

Monthly climate (temperature and precipitation) data of Jumla station (1969-2013) nearby the dry region and Jiri station (1975-2013) nearby the wet region (Figure 1) were obtained from the Department of Hydrology and Meteorology Nepal. As there are no instrumental climate records for our specific study sites/region, we also used gridded temperature and precipitation data from the global Climatic Research Unit (CRU) at a half-degree spatial resolution (CRUTS3.24, Harris, Jones, Osborn, \& Lister, 2014; https://crudata.uea.ac.uk/cru/data/hrg). The correlation statistics showed significant positive relationship of gridded climate data (MAT and mean annual precipitation, MAP) with station data of Jumla (MAT, $r=.74^{* * *}$; MAP, $r=.48^{* * *}$, duration: 19692013) and Jiri (MAT, $r=.80^{* * *}$; MAP, $r=.48^{* *}$, duration: 1975-2013). We calculated VPD from monthly maximum temperature of meteorological stations following Allen, Pereira, Raes, and Smith (1998). VPD was used as a proxy for the vapor pressure difference between leaf and air (assuming saturated vapor pressure in leaves). The drought (moisture) conditions of each study regions were derived from self-calibrating Palmer drought severity index (scPDSI, van der Schrier, Barichivich, Briffa, \& Jones, 2013). The scPDSI is a meteorological drought index and estimates the moisture conditions by incorporating precipitation and temperature, soil moisture demand and supply, into a primitive hydrological accounting system (van der Schrier et al., 2013). The scPDSI dataset was obtained from global CRU grids (https://crudata.uea.ac.uk/ $\mathrm{cru} /$ data/drought/) at half-degree spatial resolution (Figure 1).

\section{5 | Statistical analyses}

\subsection{1 | Long-term changes in water-use efficiency}

In each region and elevation belt, we reconstructed the temporal trends of $C_{i} / C_{a}$ ratios of Himalayan fir and compared this with three theoretical scenarios of stomatal regulation with increasing $C_{a}$ : (a) $C_{i}$ remained constant over time (active response: strong reduction of stomatal conductance); (b) $\mathrm{C}_{\mathrm{i}} / \mathrm{C}_{\mathrm{a}}$ remained constant over time (active response: reduction of stomatal conductance); and (c) $C_{i}-C_{a}$ remained constant over time (passive response: no change in stomatal conductance; Linares \& Camarero, 2012; McCarroll et al., 2009).

We used linear mixed-effects models to test long-term trends in iWUE at each combination of elevation belt and region (Equation 7). In each mixed-effects model, calendar year (Year) and tree size (DBH; Nock et al., 2011) were included as fixed factors, and individual tree (TreeNo) as a random factor. We also analyzed effect of elevation (in interaction with calendar year) on iWUE (Equation 8). Models with only a random intercept were compared to models with both a random intercept and slope. The most parsimonious model was selected based on the lowest Akaike information criterion (AIC) value and estimated $p$-value. We predicted on long-term trends in iWUE for mean DBH, mean DBH - $1 S D$, and mean DBH + $1 S D$. We used the Ime4 (version 1.1-19) package in R (R Core Team, 2018). We calculated conditional $R^{2}$ (variance explained by both fixed and random variables) and marginal $R^{2}$ (variance explained by fixed variables alone) for each mixed-effects model using the package MuMIn (version 1.43.6) in R.

$$
\begin{aligned}
& \mathrm{iWUE} \sim \text { Year }+\mathrm{DBH}+\text { Year } \times \mathrm{DBH}+(1 \mid \text { TreeNo }), \\
& \mathrm{iWUE} \sim \text { Year }+ \text { Elev }+ \text { Year } \times \text { Elev }+(1 \mid \text { TreeNo }) .
\end{aligned}
$$

\subsection{2 | Tree growth-climate relationship}

Growth-climate relationships were determined by bootstrapped correlation analysis. The TRW data for each elevational belt and both the dry and wet region were related to monthly series of CRU gridded climate data since $1960-2013$ as well as climate data of nearby meteorological stations. We calculated correlation coefficients after bootstrapping over a 15 month window from August of the previous growth year to current year October. As station data and gridded data showed high-to-very high positive correlations and growthclimate relationship based on both datasets were very similar, we only present the results using gridded climate data as these covered a longer period.

\subsection{3 | Long-term growth trends detection}

We used linear mixed-effects models (Equations 9 and 10) to detect long-term trends in tree growth at fixed tree sizes, following the "size class isolation" method (Peters et al., 2015). Tree growth was expressed as tree-ring width $\left(\mathrm{TRW}_{\mathrm{sci}}\right)$ or basal area increment $\left(\mathrm{BAl}_{\mathrm{sci}}\right)$ and mixed-effect models were constructed with tree growth as dependent variable, "Year" as fixed factors, and size class (10, 15, 20,25 , or $30 \mathrm{~cm} \mathrm{DBH}$ ) as random factor. We analyzed long-term 
growth trends for each elevation belt separately, in both the dry and wet region. Furthermore, we also used mixed-effects models to test the interactive effect of calendar year and elevation on long-term changes of tree growth (either $\mathrm{TRW}_{\mathrm{sci}}$ or $\mathrm{BAl}_{\mathrm{sci}}$ ) by adding elevation belt as fixed factor.

$$
\mathrm{TRW}_{\mathrm{sci}}\left(\text { or } \mathrm{BAI}_{\mathrm{sci}}\right) \sim \text { Year }+(1 \mid \text { Size class }) \text {, }
$$

$\mathrm{TRW}_{\text {sci }}\left(\right.$ or $\left.\mathrm{BAI}_{\mathrm{sci}}\right) \sim$ Year + Elev + Year $\times$ Elev $+(1 \mid$ Size class $)$.

We constructed two additional sets of mixed-effects models to detect, or account for, effects of sampling biases and age distribution. First, a "slow grower survivorship" bias (Brienen et al., 2012) could occur if trees that grow slowly have a larger chance to reach high age, implying that older trees in the sample tend to be slow growers. This could lead to apparent positive growth trends. One way to partially accommodate this bias is by selecting only recent growth rates from the dataset. We there-

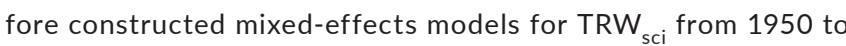
2013. This subsetting has the added advantage that differences in maximum age between study regions do not influence results. The disadvantage is that sample size is truncated and that effects of recent climatic changes have a stronger effect on growth trends since 1950; thus complicating interpretation of the differences between models. Second, negative growth trends may be induced by the "juvenile selection" effect (Brienen et al., 2012), the reverse of the "slow grower survivorship" bias. This leads to apparent negative growth trends if fast-growing juvenile individuals have a higher survival probability. To detect this potential bias, we performed quantile regressions after a regional curve standardization (RCS) to test whether trends in growth residuals differ between fast- and slow growers, such that slow growers are selectively removed from the population (Groenendijk et al., 2015). In all cases, mixed-effects models with only a random intercept were compared to models with both a random intercept and slope. The most parsimonious models among subsets of nested models were selected based on lowest $p$-value and AIC value. Predictions of the "year" effect were generated by maximum likelihoods after 1,000 bootstraps using BootMer in the package Ime4 (version 1.1-19) in R.

\section{RESULTS}

\section{1 | Chronology statistics}

Altogether, 10 new chronologies (five for each of dry and wet region) of high-elevation Himalayan fir were developed along elevation gradients in the central Himalaya (Table 1). These chronologies were spanning 206-382 years in the dry region and 92-397 years in the wet region. The average annual radial growth rate (AGR, $\mathrm{mm} /$ year) values were higher in the wet region than in the dry region. The AGR along elevation gradients ranged from 1.31 to $1.81 \mathrm{~mm}$ for dry region and 1.45 to $3.67 \mathrm{~mm}$ for wet region. The mean sensitivity (MS) showed decreasing trends with elevation in both dry and wet regions, and ranged from 0.17 to 0.24 for dry and 0.15 to 0.27 for wet region (Table 1). Tree-ring chronologies revealed moderate to high mean inter-tree correlations $\left(R_{\mathrm{bar}}\right)$ along elevation gradients in each study region. The $R_{\text {bar }}$ ranged from 0.35 to 0.43 for dry and 0.38 to 0.55 for wet region (Table 1$)$. Tree-ring chronologies revealed growth synchrony along elevation gradients of both study regions, indicating the region-specific common climatic forcing (Figure S4).

\subsection{Trends in $\mathrm{C}_{\mathrm{i}} / \mathrm{C}_{\mathrm{a}}$ ratios and iWUE}

Plant internal $\left[\mathrm{CO}_{2}\right]\left(\mathrm{C}_{\mathrm{i}}\right)$ of Himalayan fir increased over time during 1900-2013 at all elevations in both dry and wet regions with the increase of atmospheric $\left[\mathrm{CO}_{2}\right]\left(\mathrm{C}_{\mathrm{a}}\right.$; Figure 2; Figure $\left.\mathrm{S} 5\right) . \mathrm{C}_{\mathrm{i}} / \mathrm{C}_{\mathrm{a}}$ ratios were constant over time in the wet region and for the upper elevation in the dry region (Figure 2b). But, the long-term variation in $\mathrm{C}_{\mathrm{i}} / \mathrm{C}_{\mathrm{a}}$ ratios showed decreasing trends over time for the lower elevations in the dry region, where the relationship was statistically significant at the lowermost elevation $(2,800 \mathrm{~m})$ and marginally significant $(p=.06)$ at the middle elevation $(3,300 \mathrm{~m}$; Figure $2 \mathrm{a})$. These results suggest $a$ " $C_{i}=$ constant" scenario (reduction of $C_{i} / C_{a}$ ) at the lower elevations in the dry region which is consistent with the response expected from decrease of stomatal conductance. In the wet region, the constant $\mathrm{C}_{\mathrm{i}} / \mathrm{C}_{\mathrm{a}}$ also suggests an active stomatal response to $\mathrm{CO}_{2}$ rise (McCarroll et al., 2009).

Carbon isotopic composition $\left(\delta^{13} \mathrm{C}\right)$ decreased over time at all elevations in both dry and wet regions (Figure S6). Consequently, iWUE ( $\mu \mathrm{mol} / \mathrm{mol}$ ) of each individual Himalayan fir tree consistently increased over time at all elevations in both dry and wet regions (Figure S7), with iWUE increasing most strongly since the mid1970s, together with ambient $\left[\mathrm{CO}_{2}\right]\left(\mathrm{C}_{\mathrm{a}}\right)$. The fixed effects of elevation itself revealed little contribution of iWUE changes over time in both dry and wet regions (Table S1). However, linear mixed-effects models revealed interactive effects of calendar year and tree size (Table 2). Although, iWUEs increased over time across all sized trees at all elevation belts in the dry region, the iWUE increase was stronger in bigger trees (i.e., mean + $1 S D$ and mean) compared to smaller trees (Figure S8a). In the wet region, iWUE increased for trees of all sizes at the lower elevation but decreased for smaller trees at the middle and higher elevation (Figure $\mathrm{S} 8 \mathrm{~b}$ ). The conditional $R^{2}$ and marginal $R^{2}$ values in most models suggest that the included fixed effects explain a large percentage of the variation.

\section{3 | Climate sensitivity}

Tree radial growth of Himalayan fir revealed region-specific climate sensitivity, but similar responses along the elevation gradients. Tree-growth showed a clear negative relationship with spring temperatures, and a positive relationship with spring (April-May) 
(a) Dry

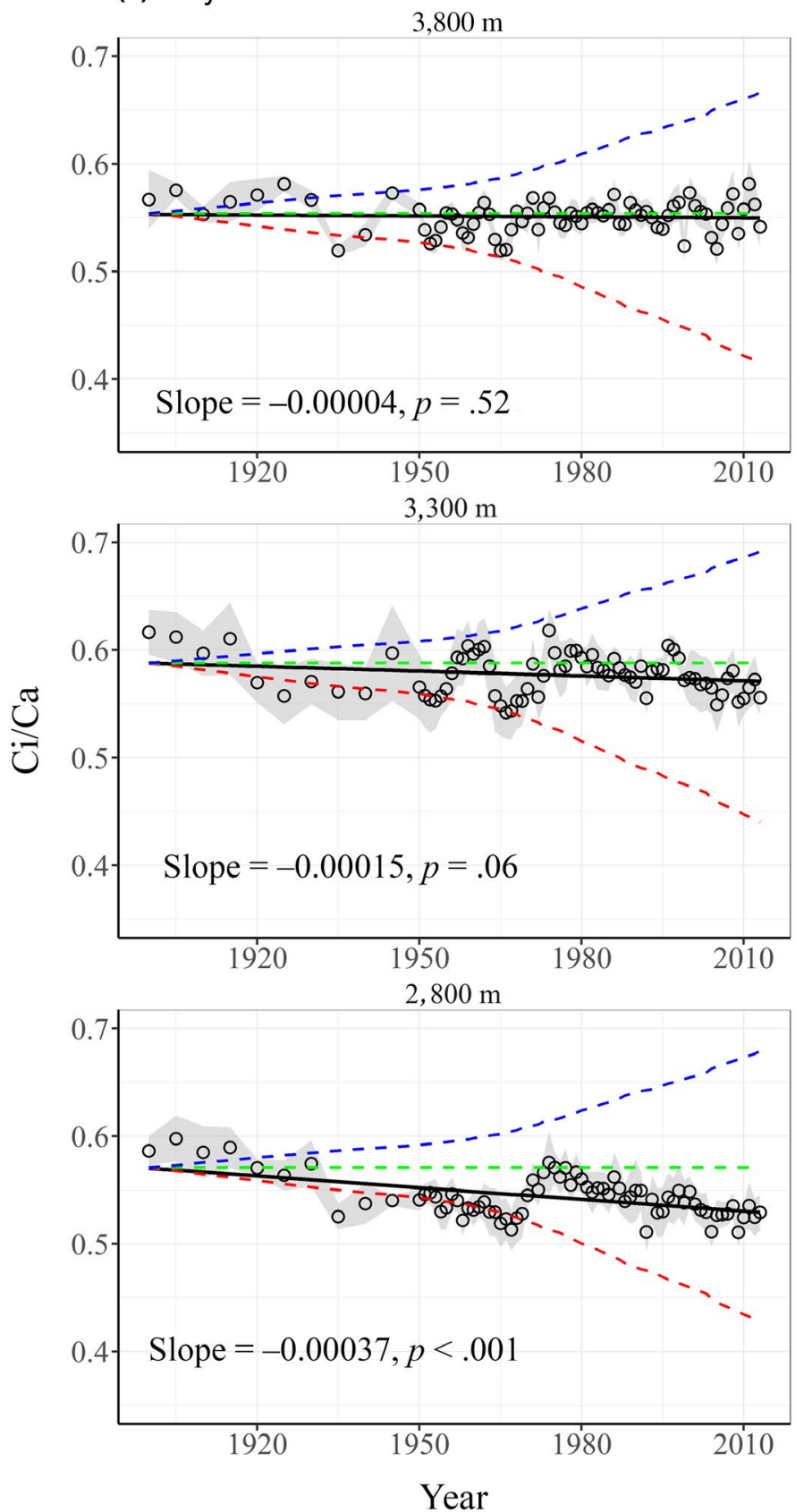

(b) Wet
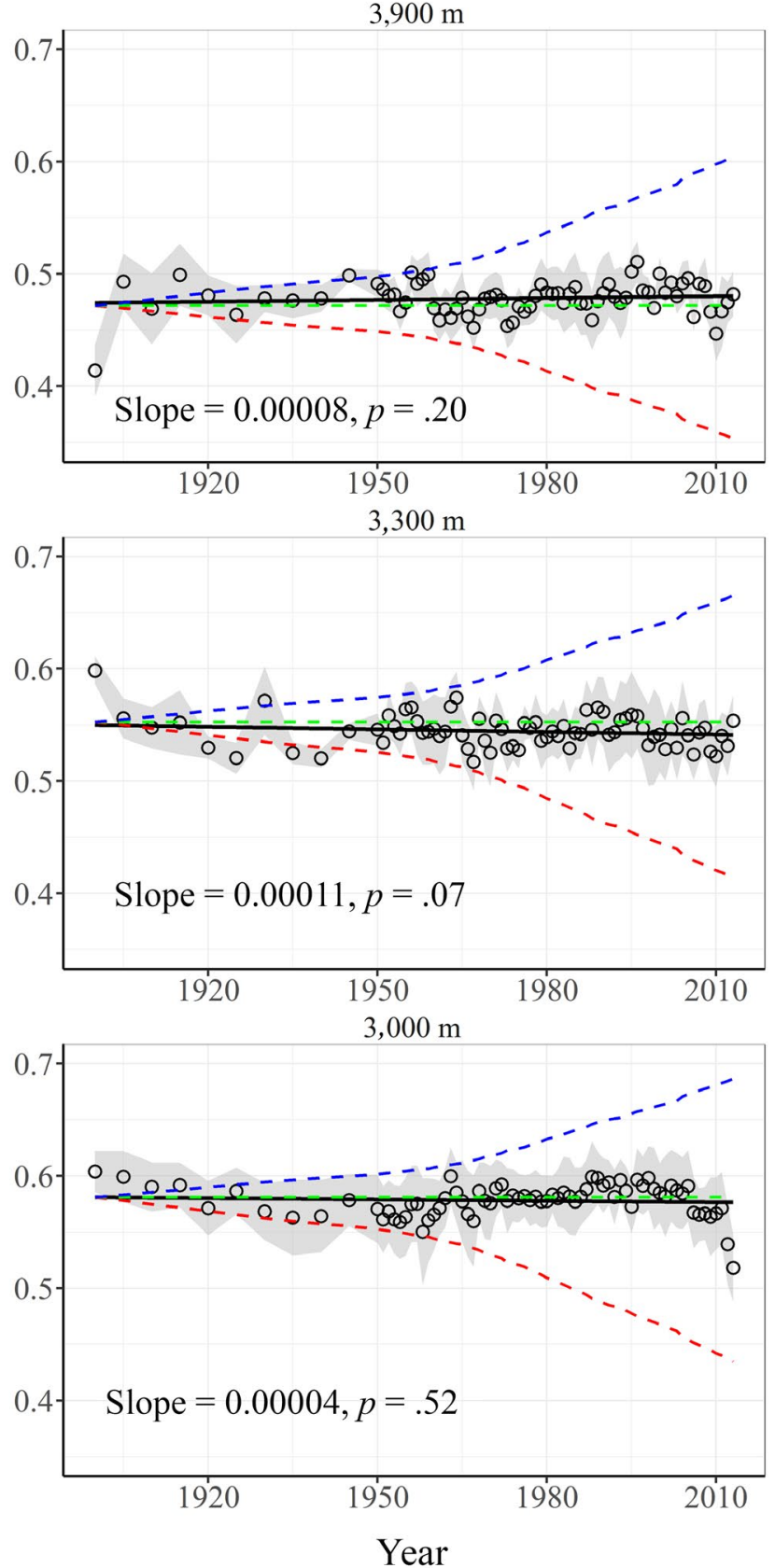

FIGURE 2 Long-term reconstructions of $C_{i} / C_{a}$ ratios of Himalayan fir during 1900-2013 in dry (a) and wet (b) regions contrasting in rainfall and at three elevational belts in each region in the central Himalaya. Each open black circle represents the mean value of four trees; gray shading is standard deviation among trees. Solid black lines are fitted regression slopes of $C_{i} / C_{a}$ over time with their significance. Three theoretical scenarios of $\mathrm{C}_{\mathrm{i}} / \mathrm{C}_{\mathrm{a}}$ ratios to $\mathrm{CO}_{2}$ rise are shown with dashed lines: $\mathrm{C}_{\mathrm{i}}=$ constant (red); $\mathrm{C}_{\mathrm{i}} / \mathrm{C}_{\mathrm{a}}=$ constant (green); $\mathrm{C}_{\mathrm{a}}-\mathrm{C}_{\mathrm{i}}=$ constant (blue)

precipitation/moisture availability in the dry region (west Nepal; Figures 3 and 4). In the wet region (east Nepal), radial growth at higher elevations showed a positive relationship with temperatures of the previous winter to current year growing season. In addition, tree growth was positively correlated with summer temperatures and negatively correlated with precipitation/moisture availability during July and August, and the relationship was consistent at all elevation belts (Figures 3 and 4).

\section{4 | Long-term growth trends}

Linear mixed-effects models revealed significant declines of tree growth $\left(\mathrm{TRW}_{\text {sci }}\right.$ ) over time at the middle and low elevations in the dry and wet region (except for a nonsignificant trend at 3,000 $\mathrm{m}$ in the wet region; Figure 5; Table 3). Results for basal area increment $\left(\mathrm{BAI}_{\text {sci }}\right.$ ) were similar (Figure S9; Table S2). At the higher elevations of the wet region, tree growth trends (both in $\mathrm{TRW}_{\mathrm{sci}}$ and $\mathrm{BAI}_{\mathrm{sci}}$ ) were 


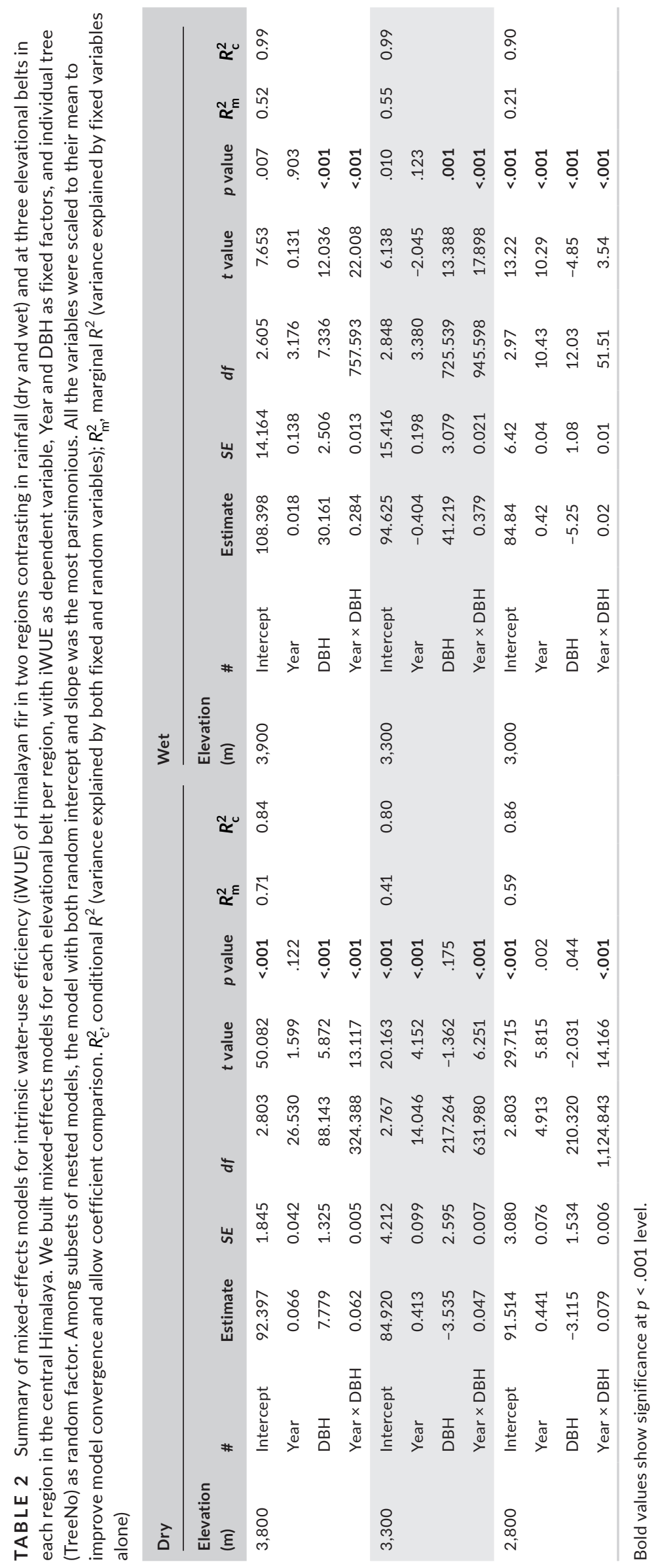



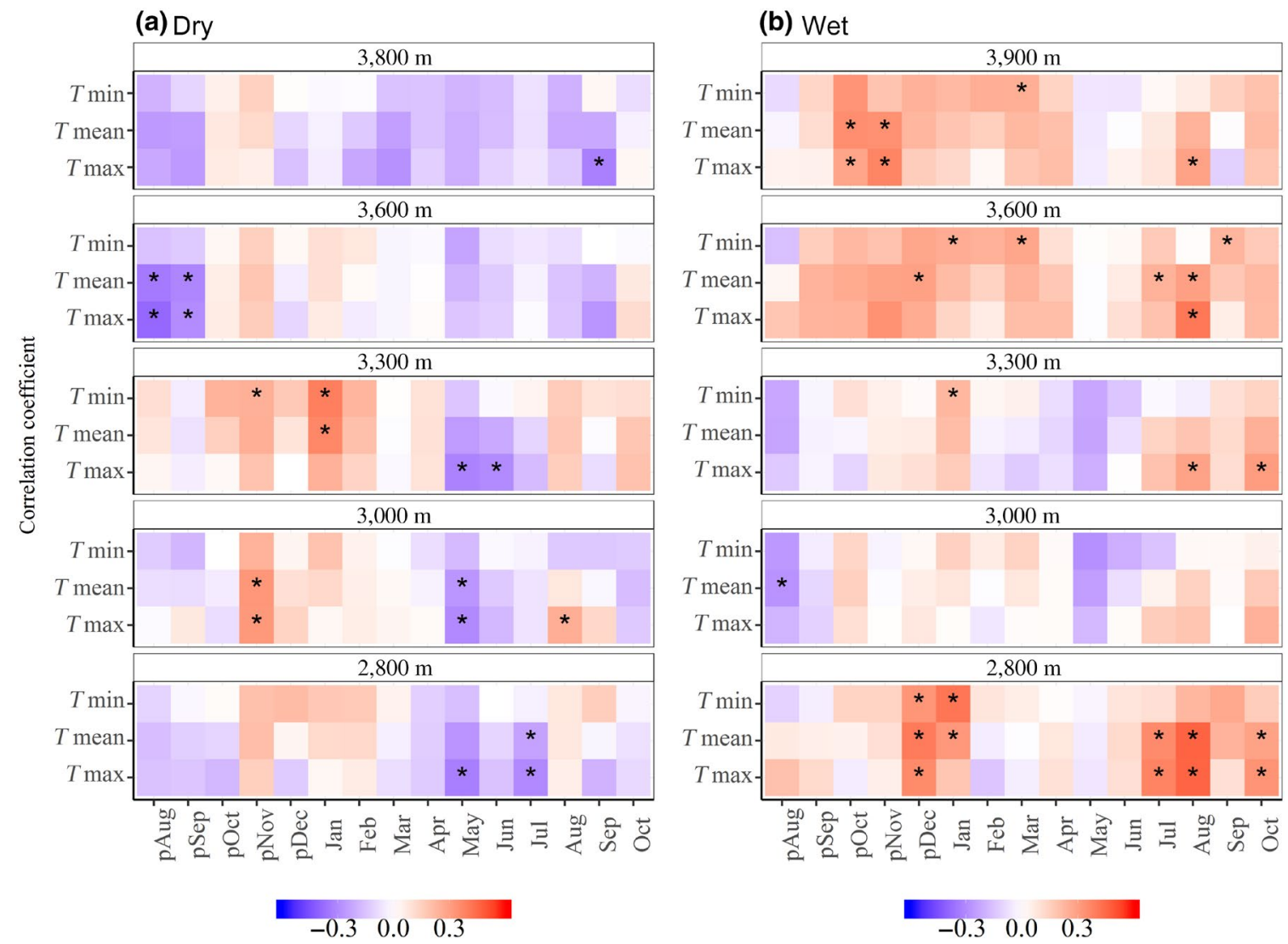

FIGURE 3 Temperature sensitivity of Himalayan fir growth in dry (a) and wet (b) regions contrasting in rainfall and temperature (five elevational belts in each region) in the central Himalaya. Correlations were computed between tree ring width chronologies and Climatic Research Unit gridded temperatures during 1960-2013 for a 15 month window from previous August to current October. $T_{\text {min }}$, minimum temperature; $T_{\text {mean }}$, mean temperature; $T_{\text {max }}$, maximum temperature. Asterisks indicate significant trends $(p<.05)$
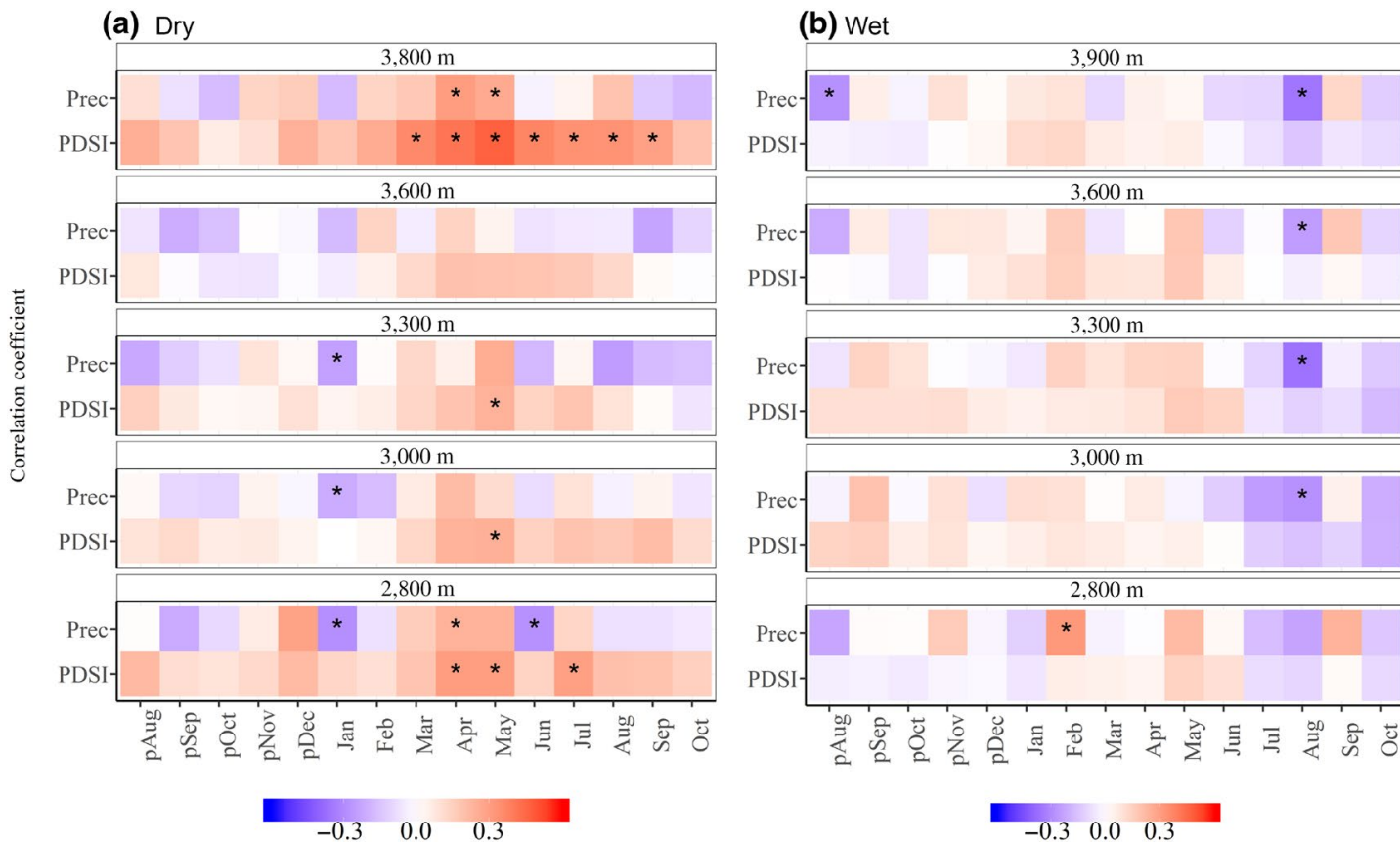

FIGURE 4 Moisture sensitivity of Himalayan fir growth in dry (a) and wet (b) regions contrasting in rainfall and temperature (five elevation belts in each region) in the central Himalaya. Correlations were computed between tree ring-width chronologies and Climatic Research Unit gridded precipitation and moisture indices during 1960-2013 for a 15 month window from previous August to current October. Prec, precipitation; PDSI, self-calibrating Palmer drought severity index. Asterisks indicate significant trends $(p<.05)$ 
(a) Dry

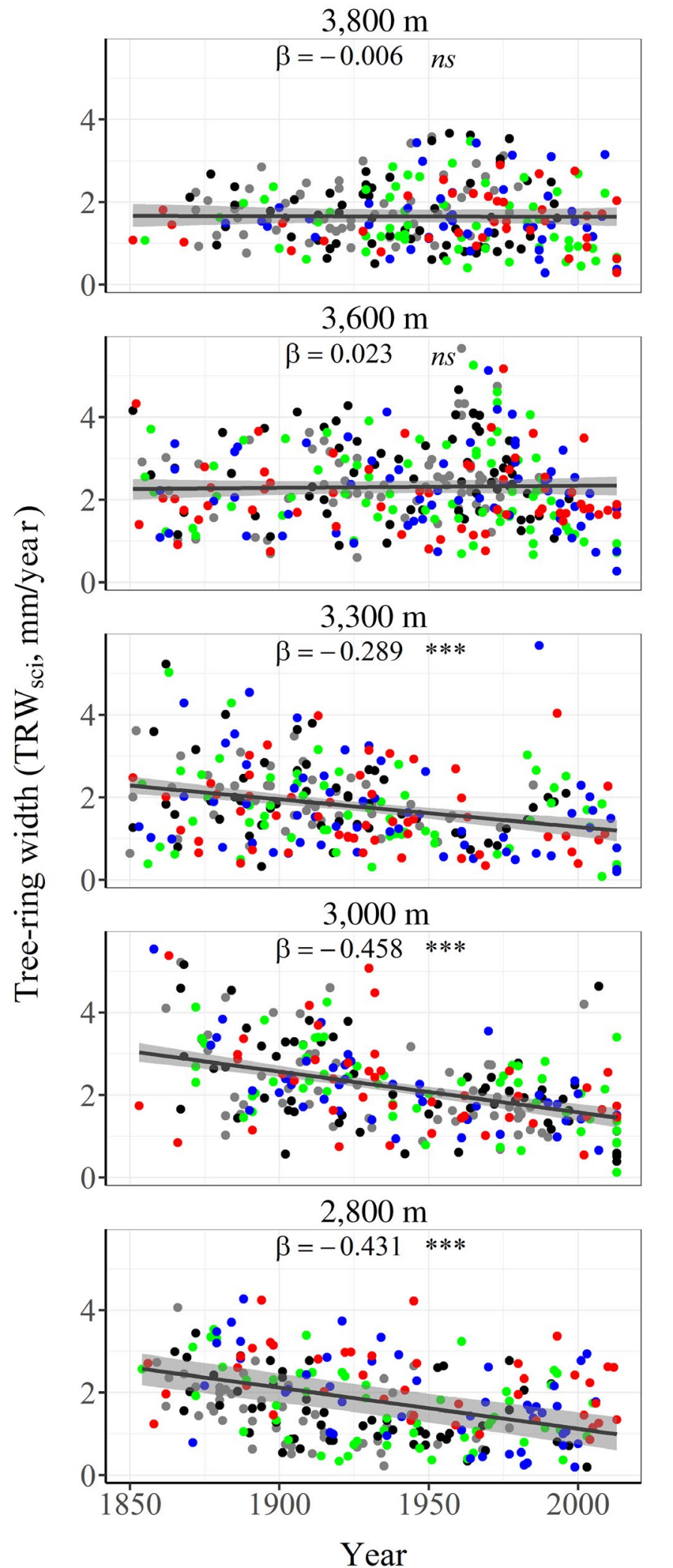

(b) Wet
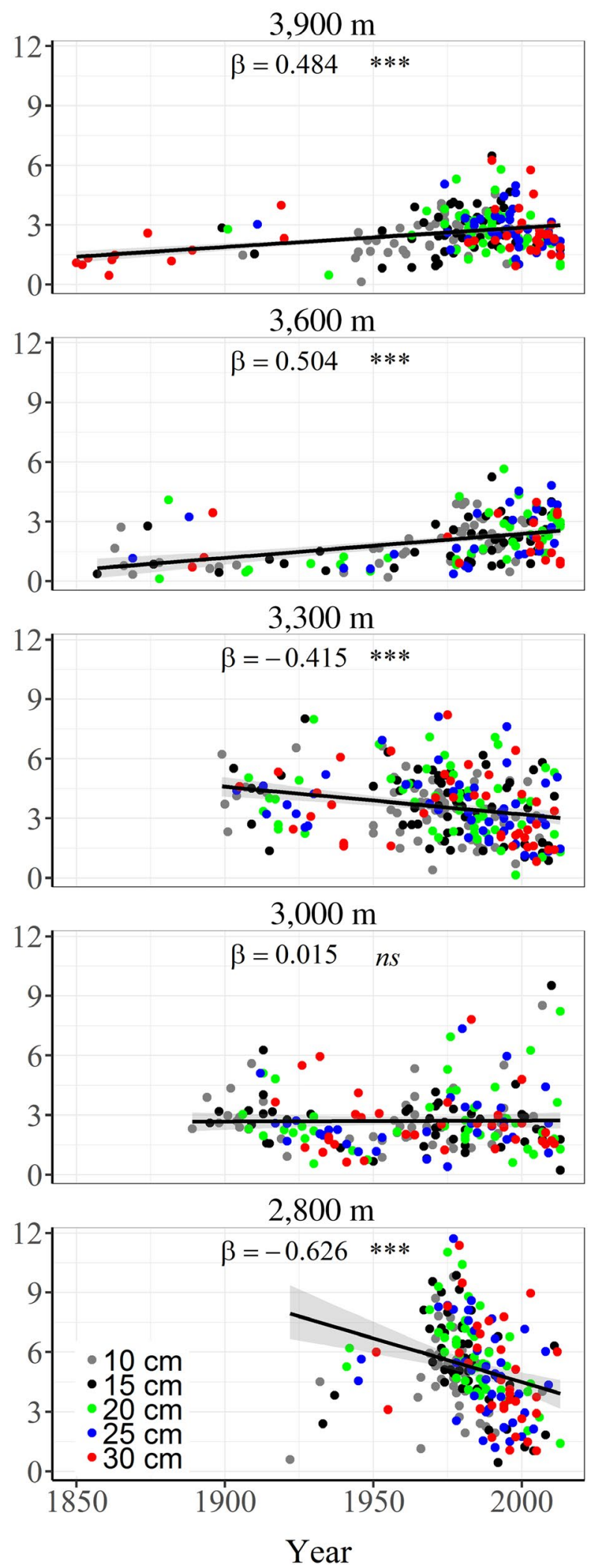

FIGURE 5 Long-term trends of tree-ring widths (TRW ${ }_{\text {sci }}$ ) of Himalayan fir in dry (a) and wet (b) regions and at five elevational belts in each region in the central Himalaya. TRW $_{\text {sci }}$ was calculated as 5 year averaged tree-ring width at five fixed tree sizes $(10,15,20,25$, and $30 \mathrm{~cm}$ in diameter) to account for ontogenetic effects on tree growth. Results of linear mixed-effects models are shown in Table 3. Lines represent effects of fixed effect "Year" (with slope " $\beta$," mm/year) and their significance: ${ }^{* * *} p<.001$; ns, no significant. Note the difference in Y-axis scale between plots for dry and wet regions 


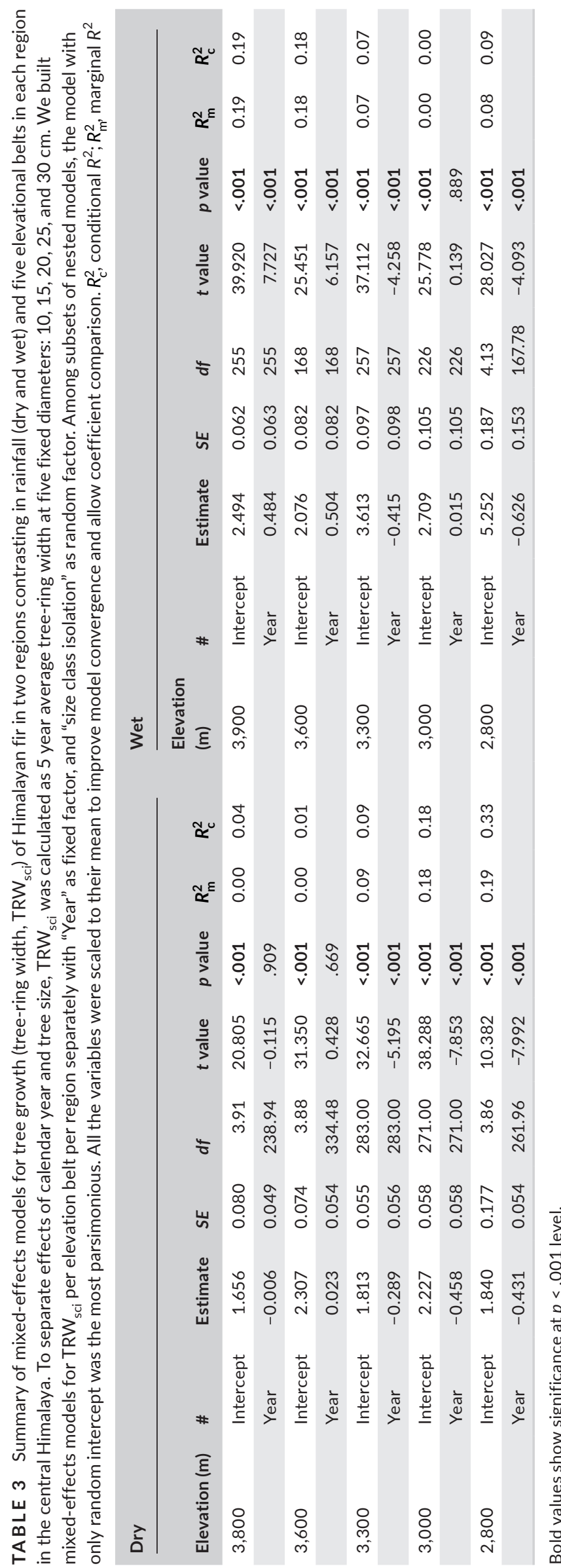

positive; no significant trend was detected at higher elevations in the dry region (Figure 5; Table 3; Figure S9; Table S2). The decreasing growth trends were generally stronger for larger trees (Figure 5). When combining all elevations in one mixed-effects model, we found significant interactive effect of calendar year and elevation on growth at low and middle elevations in both dry and wet region, indicating that growth trends differed significantly across elevations (Tables S3 and S4). Overall, we found more negative trends at low and middle elevation and positive trends only at the two highest elevations in the wet region.

The trends of the residuals after RCS also revealed good agreement with the trends using $\mathrm{SCl}$. Seven out of 10 trends have similar sign while a significant trend was observed at $3,800 \mathrm{~m}$ (positive) and $3,600 \mathrm{~m}$ (negative) in the dry region and the trend was statistically nonsignificant at 2,800 $\mathrm{m}$ in the wet region (Figure S10; Table S5). Divergence of growth trends between the upper quantiles (fastest grower) and lower quantiles (slowest grower) for the juvenile trees $(\mathrm{DBH} \leq 20 \mathrm{~cm}$ ) revealed the potential existence of a "juvenile selection" bias at 2,800 $\mathrm{m}$ in the dry region and at 3,300 and 3,000 $\mathrm{m}$ in the wet region (Figure S11; Table S6). This bias could have induced the negative growth trends found at these elevations.

We further tested whether the positive growth trend at the higher elevations in the wet region could be caused by the presence of old, slow-growing individuals in the sampled population (Figure S12; Table S7). When limiting the observation period to include growth from 1950 onwards, we indeed found that positive growth trends disappeared $(3,900 \mathrm{~m})$ or were reduced $(3,600 \mathrm{~m})$ in the wet region. This is consistent with an effect of "slow grower survivorship" bias. At lower elevations in the wet region, the direction of trends remained the same. In the dry region, shortening of the period caused negative trends in the low and mid elevations $(2,800-3,300 \mathrm{~m})$ to disappear. A plausible explanation for this change is the strong reduction in sample size. At high elevation in the dry region, trends shifted from nonsignificant to negative, consistent with a stronger drying trend and climate warming during this period.

\section{4 | DISCUSSION}

\section{1 | Sensitivity of tree radial growth to climate variability}

Our results revealed decreasing MS with increasing elevation in both dry and wet regions indicating that trees at lower elevation are more sensitive to year-to-year climate variations. MS in both regions was in a similar range as that reported for $A$. spectabilis, and other conifers, from the Himalayas and nearby regions (Gaire, Bhuju, et al., 2017; Panthi et al., 2017; Panthi, Bräuning, Zhou, \& Fan, 2018; Shrestha et al., 2017). High year-to-year fluctuations in temperature and precipitation (moisture availability) at lower elevation belts are likely related to stronger temperature sensitivity in the dry region and thus enhanced warming-induced drought stress 
(moisture demand) of tree growth (Liang et al., 2016). Tree growth at upper treeline in the dry regions of the Himalaya was also found to be moisture limited in other studies (Liang et al., 2014; Sigdel et al., 2018). Similarly, positive (winter and summer) temperature sensitivity at higher (mainly 3,900 and 3,600 m) and lowest (2,800 m) elevation belts is clearly visible in the wet region, and was supported by the earlier findings of Shrestha et al. (2017) in the humid northfacing slopes of the Himalaya.

\subsection{Long-term tree physiological changes}

We found a consistent increase in iWUE and near-constant $\mathrm{Ci} / \mathrm{Ca}$ ratios of Himalayan fir trees over the past century at all elevations in the wet region and at higher elevation in the dry region. These responses suggest that temperature rise (through increasing VPD) at these sites did not have a dominant effect on tree physiology, nor did a potential drying trend that occurred at lower elevations and dry regions. Constant $C_{i} / C_{a}$ ratios over time have also been reported for other conifers at high latitudes (Andreu-Hayles et al., 2011; Frank et al., 2015; Lévesque et al., 2014; Martínez-Sancho et al., 2018) and other high-elevation tree species (Huang et al., 2017).

At the low elevations in the dry region, we found significant decreases in $C_{i} / C_{a}$ ratio which are consistent with a stomatal response that is regulated by other factors than rising $C_{a}$. Possible causes of this response include warming $\left(0.4^{\circ} \mathrm{C}\right.$ per decade for maximum temperature) which could have led to reduction of $\mathrm{C}_{\mathrm{i}} / \mathrm{C}_{\mathrm{a}}$ through increasing VPD and/or drying (decreasing moisture availability and rainfall reduction), both of which occurred in the dry region (Figure S1). Both climatic trends may have caused stronger stomatal closure than expected based on $\mathrm{C}_{\mathrm{a}}$ rise alone. Such climate-mediated stomatal responses have also been found in previous studies (Frank et al., 2015; Peters et al., 2018). Thus, $\mathrm{C}_{\mathrm{i}} / \mathrm{C}_{\mathrm{a}}$ patterns at low elevation under dry conditions are driven by stomatal responses to water availability and VPD, in addition to $\mathrm{CO}_{2}$ rise. Our results confirm findings of earlier studies showing that iWUE trends vary between regions and are modified by mean climate (Frank et al., 2015; Lévesque et al., 2014; MartínezSancho et al., 2018; Peters et al., 2018; Saurer et al., 2014). We found substantial differences in iWUE trends across tree sizes (cf. Brienen, Gloor, Clerici, et al., 2017). Larger trees consistently exhibited stronger increases in iWUE, probably because they have more exposed canopy position and a higher water demand, leading to stronger stomatal responses to the presumed rise in VPD, warming, and drought.

\subsection{Detecting and explaining long-term trends}

Our long-term growth analyses of Himalayan fir revealed decreasing growth trends at lower elevations (in both dry and wet regions), an increasing trend at higher elevations in the wet region and no significant changes at higher elevations in the dry region. These divergent long-term growth trends may be caused not only by elevation-specific physiological responses to atmospheric and climatic changes but also by differences in climatic drivers of wood formation at different elevations.

The detection of long-term growth trends based on tree-ring analysis is complicated by several potential biases (Brienen et al., 2012; Brienen, Gloor, \& Ziv, 2017). The "big tree selection" bias, which may result in positive growth trends over time, was avoided by our sampling design (i.e., by including trees of all sizes). The analysis of growth trends after 1950, suggested that a "'slow grower survivorship" bias (Bigler, 2016; Bigler \& Veblen, 2009; Büntgen et al., 2019) may have occurred at $3,900 \mathrm{~m}$ in the wet region (Figure S12). For this elevation, the positive trend found for the full study period, changed into a nonsignificant trend if data only after 1950 were used. Lastly, if fast-growing juvenile individuals have a higher survival probability, then large trees sampled at present were the fast-growing juveniles of the past, whereas the small trees sampled at present will include more slow-growing individuals (Groenendijk et al., 2015; van der Sleen et al., 2015). The quantile regression after RCS detrending for juvenile trees $(\mathrm{DBH} \leq 20 \mathrm{~cm}$; Groenendijk et al., 2015) revealed the potential existence of such "juvenile selection" bias at 2,800 $\mathrm{m}$ in the dry region and at 3,300 and $3,000 \mathrm{~m}$ in the wet region (Figure S11). In these regions, no growth trend was found in the fastest growers over time (the upper quantile), whereas as a significant negative trend was found in the slowest growers over time. The latter result could thus be attributed to an increase of slow-growing individuals in the dataset over time. These results suggest that reported negative growth trends for $2,800 \mathrm{~m}$ in the dry region and $3,300 \mathrm{~m}$ in the wet region could have been overestimated or could be constant. Thus, we are confident about the sign and magnitude of seven of 10 reported growth trends. After this bias check, the overall pattern of predominant negative growth trends occurred at low and mid elevations, and the only positive trend was found for a high-elevation site.

At low elevations $(<3,600 \mathrm{~m})$, the negative growth trend in the dry region can be attributed to the combination of increasing temperature and VPD (causing stomatal closure and a limited $\mathrm{CO}_{2}$ fertilization effect on photosynthesis; Figure 2) and a negative effect of temperature on growth (Figure 3). In general, such negative growth trends may be explained by increasing source limitation of tree growth (through reduced photosynthesis) or by increasing sink limitation (through turgor limitation of growth) is unclear (Körner, 2015). In the wet region, negative growth trends are less common (after bias check: one of three trends is negative). This negative trend $(2,800 \mathrm{~m})$ cannot be explained by drought-induced responses of $C_{i} / C_{a}$ (Figure 2) or temperature sensitivity of tree growth (summer temperature has a positive effect, Figure 3). Yet, warming-induced drought effects on tree growth may also have played a role here, likely mainly through sink limitation. Our findings of negative or stable growth trends during the past century agree with those of other studies on coniferous species in temperate montane (Lévesque et al., 2014; Linares \& Camarero, 2012) and boreal forests 
(Giguère-Croteau et al., 2019; Girardin, Bouriaud, et al., 2016), and broad-leaved species in tropical lowland forests (Groenendijk et al., 2015; Nock et al., 2011).

At high elevations (3,600 $\mathrm{m}$ and above), we found growth trends were either nonsignificant or positive. The positive growth trend in the wet region can be attributed to the combination of warming and consistent positive temperature sensitivity of annual growth (Figure 3), alongside positive effects of $\mathrm{CO}_{2}$ rise on photosynthesis. Thus, trees at these elevational belts likely benefitted from increased temperatures as this extended the length of the growing season via earlier onset and late end of xylogenesis. The concurrent rise in temperature and $\mathrm{C}_{\mathrm{a}}$ does not allow assessing to what extent the positive growth trend can be attributed to $\mathrm{CO}_{2}$ fertilization effects or to the removal of temperature-driven sink limitation (Körner, 2015). Positive temperature-growth relationships are commonly found at higher elevations in the alpine ecotone (Dolezal et al., 2019; Panthi et al., 2018), and tree growth acceleration in alpine regions has also been found in other studies (Huang et al., 2017; Lindner et al., 2010; Paulsen, Weber, \& Korner, 2000; Qi et al., 2015; Salzer et al., 2009; Silva et al., 2016). In the dry region, warming also likely reduced temperature-driven sink limitation, and increased the season during which temperature allowed tree growth. Yet, this did not lead to positive growth trends. Possible explanations include moisture limitations in combination with warming-induced increase in drought. The latter has probably not played an important role, as $\mathrm{C}_{\mathrm{i}} / \mathrm{C}_{\mathrm{a}}$ trends (Figure 2 ) are not consistent with a stomatal response expected under increasing drought stress. One approach to better understand tree growth limiting factors is to employ the stem diameter variation and sap flux measurement to determine the extent to which tree stem growth is sink- or source limited (Fatichi, Pappas, Zscheischler, \& Leuzinger, 2019; Steppe, Crone, \& Pauw, 2016; Zuidema, Poulter, \& Frank, 2018).

In summary, we found that long-term physiological and growth responses of Himalayan fir to multiple environmental changes are mediated by the mean climatic conditions. Thus, trends in iWUE and growth varied with elevation and rainfall regime. We also found that trends in iWUE, $\mathrm{C}_{\mathrm{i}} / \mathrm{C}_{\mathrm{a}}$ and growth were likely driven by various climatic and atmospheric changes $\left(\mathrm{CO}_{2}\right.$ rise, warming, drying). Thus, in our study region, physiological and growth responses of fir trees are driven by a combination of continental-scale warming and $\mathrm{CO}_{2}$ rise, and regional drying trends. The negative growth trends at lower elevation, in both wet and dry regions, suggest that warming-induced drought responses drive tree growth more than $\mathrm{CO}_{2}$ rise induced increases in photosynthesis and water saving. Similarly, at mid and high elevations, where temperature strongly limits the length of growing season, a positive effect of warming on tree growth may have been outweighed by the negative effects of warming-induced moisture limitations (mainly in dry region). Our results contribute to a better understanding of the responses of high-elevation forests to climatic and atmospheric changes. We found that positive effects of $\mathrm{CO}_{2}$ rise through photosynthesis and water relations (both reducing source limitation) did not mitigate the negative effects of warming and drying (increasing source and/or sink limitation) on tree growth. The decreasing growth trends at low to middle elevations raise concerns on the productivity and dynamics of fir forests as climate change progresses. Climate-induced reduction of tree growth in high-elevation forests could have far-reaching impacts for the important ecosystem services currently provided by Himalayan forests.

\section{ACKNOWLEDGEMENTS}

This work was funded by the National Natural Science Foundation of China (NSFC, 3186113307, 31770533), National Key Research Development Program of China (2016YFC0502105), and the CAS 135 Program (2017XTBG-T01). SP and PZ were supported by "The CAS President's International Fellowship Initiative" (PIFI) postdoctoral fellowship (2019PC0104) and visiting scientist project (2018VCA0037), respectively. PvdS was supported by a Marie Curie Individual Fellowship (746181). We acknowledge the Department of National Parks and Wildlife Conservation Nepal, Rara National Park and Gaurishankar Conservation Area for providing permission for field sampling. Department of Plant Resources and Ministry of Forest and Environment (Nepal Government) provided the permission for exporting tree-ring samples from Nepal to China. Meteorological data were obtained from Department of Hydrology and Meteorology, Nepal. Special thanks to Mr. Janardan Mainali, Mr. Rajesh Tamang, and local assistances for their help during the fieldworks. We thank the central laboratory of XTBG for stable isotope measurements. We thank Dr. Pei-Li Fu for his help during alpha cellulose extraction, and Prof. Kyle Tomlinson for his constructive suggestions in the manuscript.

\section{CONFLICT OF INTEREST}

The authors declare no competing financial and any other potential conflict of interests.

\section{ORCID}

Shankar Panthi iD https://orcid.org/0000-0002-3522-5555

Ze-Xin Fan (iD) https://orcid.org/0000-0003-4623-6783

Pieter A. Zuidema (ID https://orcid.org/0000-0001-8100-1168

\section{REFERENCES}

Allen, R. G., Pereira, L. S., Raes, D., \& Smith, M. (1998). Crop evapotranspiration: Guidelines for computing crop water requirements. FAO Irrigation and drainage paper 56. Rome, Italy.

Andreu-Hayles, L., Planells, O., Gutiérrez, E., Mantan, E., Helle, G., Anchukaitis, K. J., \& Schleser, G. H. (2011). Long tree-ring chronologies reveal 20th century increases in water-use efficiency but no enhancement of tree growth at five Iberian pine forests. Global Change Biology, 17, 2095-2112. https://doi.org/10.1111/j.1365-2486.2010.02373.x

Barber, V. A., Juday, G. P., \& Finney, B. P. (2000). Reduced growth of Alaskan white spruce in the twentieth century from temperature-induced drought stress. Nature, 405, 668-673. https://doi. org/10.1038/35015049

Barry, R. G. (2008). Mountain weather and climate (3rd ed.). New York, NY: Cambridge University Press.

Bigler, C. (2016). Trade-offs between growth rate, tree size and lifespan of mountain pine (Pinus montana) in the Swiss National Park. PLoS ONE, 11(3), e0150402. https://doi.org/10.1371/journ al.pone.0150402 
Bigler, C., \& Veblen, T. T. (2009). Increased early growth rates decrease longevities of conifers in subalpine forests. Oikos, 118(8), 1130-1138. https://doi.org/10.1111/j.1600-0706.2009.17592.x

Böhner, J., Miehe, G., Miehe, S., \& Nagy, L. (2015). Climate and weather. In G. Miehe, C. A. Pendry, \& R. P. Chaudhary (Eds.), Nepal: An introduction to the natural history, ecology and human environment of the Himalayas (pp. 385-472). Edinburgh, UK: Royal Botanic Garden.

Bonan, G. B. (2008). Forests and climate change: Forcings, feedbacks, and the climate benefits of forests. Science, 320, 1444-1449. https:// doi.org/10.1126/science.1155121

Brienen, R. J. W., Gloor, E., Clerici, S., Newton, R., Arppe, L., Boom, A., ... Timonen, M. (2017). Tree height strongly affects estimates of water-use efficiency responses to climate and $\mathrm{CO}_{2}$ using isotopes. Nature Communications, 8(1), 2888. https://doi.org/10.1038/ s41467-017-00225-z

Brienen, R. J., Gloor, E., \& Zuidema, P. A. (2012). Detecting evidence for $\mathrm{CO}_{2}$ fertilization from tree ring studies: The potential role of sampling biases. Global Biogeochemical Cycles, 26(1), GB1025. https://doi. org/10.1029/2011GB004143

Brienen, R. J., Gloor, M., \& Ziv, G. (2017). Tree demography dominates long-term growth trends inferred from tree rings. Global Change Biology, 23(2), 474-484. https://doi.org/10.1111/gcb.13410

Bunn, A. G. (2008). A dendrochronology program library in $R$ (dpIR). Dendrochronologia, 26(2), 115-124. https://doi.org/10.1016/j.dendro. 2008.01.002

Büntgen, U., Krusic, P. J., Piermattei, A., Coomes, D. A., Esper, J., Myglan, V. S., ... Körner, C. (2019). Limited capacity of tree growth to mitigate the global greenhouse effect under predicted warming. Nature Communication, 10(1), 2171. https://doi.org/10.1038/ s41467-019-10174-4

Charney, N. D., Babst, F., Poulter, B., Record, S., Trouet, V. M., Frank, D., ... Evans, M. E. K. (2016). Observed forest sensitivity to climate implies large changes in 21st century North American forest growth. Ecology Letters, 19(9), 1119-1128. https://doi.org/10.1111/ele.12650

Dawes, M. A., Hättenschwiler, S., Bebi, P., Hagedorn, F., Handa, I. T., Korner, C., \& Rixen, C. (2010). Species-specific tree growth responses to 9 years of $\mathrm{CO}_{2}$ enrichment at the alpine treeline. Journal of Ecology, 99(2), 383-394. https://doi.org/10.1111/j.1365-2745.2010.01764.x

DNPWC. (2015). Rara National Park. In M. Dhakal (Ed.), Protected areas of Nepal (pp. 17-18). Kathmandu, Nepal: Department of National Parks and Wildlife Conservation.

Dolezal, J., Kopecky, M., Dvorsky, M., Macek, M., Rehakova, K., Capkova, K., ... Altman, J. (2019). Sink limitation of plant growth determines treeline in the arid Himalayas. Functional Ecology, 33, 553-565. https://doi.org/10.1111/1365-2435.13284

Farquhar, G. D., O'Leary, M. H., \& Berry, J. A. (1982). On the relationship between carbon isotope discrimination and the intercellular carbon dioxide concentration in leaves. Australian Journal of Plant Physiology, 9, 121-137. https://doi.org/10.1071/PP9820121

Fatichi, S., Pappas, C., Zscheischler, J., \& Leuzinger, S. (2019). Modelling carbon sources and sinks in terrestrial vegetation. New Phytologist, 221(2), 652-668. https://doi.org/10.1111/nph.15451/

Francey, R. J., \& Farquhar, G. D. (1982). An explanation of ${ }^{13} \mathrm{C} /{ }^{12} \mathrm{C}$ variations in tree rings. Nature, 297, 28-31. https://doi.org/10.1038/297028a0

Frank, D. C., Poulter, B., Saurer, M., Esper, J., Huntingford, C., Helle, G., ... Weigl, M. (2015). Water-use efficiency and transpiration across European forests during the Anthropocene. Nature Climate Change, 5(6), 579-583. https://doi.org/10.1038/NCLIMATE2614

Fu, L., Li, N., \& Elias, T. S. (1999). Abies. In Z. Y. Wu \& P. H. Raven (Eds.), Flora of China, volume 4: Pinaceae (pp. 11-52). St. Louis, MO: Science Press Beijing and Missouri Botanical Garden Press.

Gaire, N. P., Bhuju, D. R., Koirala, M., Shah, S. K., Carrer, M., \& Timilsena, R. (2017). Tree-ring based spring precipitation reconstruction in western Nepal Himalaya since AD 1840. Dendrochronologia, 42, 2130. https://doi.org/10.1016/j.dendro.2016.12.004
Gaire, N. P., Koirala, M., Bhuju, D. R., \& Carrer, M. (2017). Site- and species-specific treeline responses to climatic variability in eastern Nepal Himalaya. Dendrochronologia, 41, 44-56. https://doi.org/10.1016/ j.dendro.2016.03.001

Giguère-Croteau, C., Boucher, E., Bergeron, Y., Girardin, M. P., Drobyshev, I., Silva, L. C., ... Garneau, M. (2019). North America's oldest boreal trees are more efficient water users due to increased $\left[\mathrm{CO}_{2}\right]$, but do not grow faster. Proceedings of the National Academy of Sciences of the United States of America, 116(7), 2749-2754. https:// doi.org/10.1073/pnas.1816686116

Girardin, M. P., Bouriaud, O., Hogg, E. H., Kurz, W. A., Zimmermann, N. E., Metsaranta, J. M., ... Bhatti, J. S. (2016). No growth stimulation of Canada's boreal forest under half-century of combined warming and $\mathrm{CO}_{2}$ fertilization. Proceedings of the National Academy of Sciences of the United States of America, 113(52), E8406-E8414. https://doi. org/10.1073/pnas.1610156113

Girardin, M. P., Hogg, E. H., Bernier, P. Y., Kurz, W. A., Guo, X. J., \& Cyr, G. (2016). Negative impacts of high temperatures on growth of black spruce forests intensify with the anticipated climate warming. Global Change Biology, 22(2), 627-643. https://doi. org/10.1111/gcb.13072

Groenendijk, P., van der Sleen, P., Vlam, M., Bunyavejchewin, S., Bongers, F., \& Zuidema, P. A. (2015). No evidence for consistent long-term growth stimulation of 13 tropical tree species: Results from treering analysis. Global Change Biology, 21(10), 3762-3776. https://doi. org/10.1111/gcb.12955

Harris, I., Jones, P. D., Osborn, T. J., \& Lister, D. H. (2014). Updated high-resolution grids of monthly climatic observations - The CRU TS3.10 dataset. International Journal of Climatology, 34, 623-664. https://doi.org/10.1002/joc.3711

Hättenschwiler, S., Miglietta, F., Raschi, A., \& Korner, C. (1997). Thirty years of in situ tree growth under elevated $\mathrm{CO}_{2}$ : A model for future forest responses? Global Change Biology, 3(5), 463-471. https://doi. org/10.1046/j.1365-2486.1997.00105.x

Huang, J. G., Bergeron, Y., Denneler, B., Berninger, F., \& Tardif, J. (2007). Response of forest trees to increased atmospheric $\mathrm{CO}_{2}$. Critical Reviews in Plant Sciences, 26, 265-283. https://doi. org/10.1080/07352680701626978

Huang, R. U., Zhu, H., Liu, X., Liang, E., Grießinger, J., Wu, G., ... Bräuning, A. (2017). Does increasing intrinsic water use efficiency (iWUE) stimulate tree growth at natural alpine timberline on the southeastern Tibetan Plateau? Global and Planetary Change, 148, 217-226. https:// doi.org/10.1016/j.gloplacha.2016.11.017

IPCC. (2013). Summary for policymakers. In T. F. Stocker, D. Qin, G.-K. Plattner, M. Tignor, S. K. Allen, J. Boschung, \& P. M. Midgley (Eds.), Climate change 2013: The physical science basis. Contribution of working group I to the fifth assessment report of the Intergovernmental Panel on Climate Change (pp. 1-27). Cambridge, UK: Cambridge University Press.

Keeling, R. F., Piper, S. C., Bollenbacher, A. F., \& Walker, J. S. (2009). Atmospheric $\mathrm{CO}_{2}$ records from sites in the $\mathrm{SIO}$ air sampling network. In Trends: A compendium of data on global change. Oak Ridge, TN: Carbon Dioxide Information Analysis Center, Oak Ridge National Laboratory, US Department of Energy. https://doi.org/10.3334/ CDIAC/atg.035

Keenan, T. F., Hollinger, D. Y., Bohrer, G., Dragoni, D., Munger, J. W., Schmid, H. P., \& Richardson, A. D. (2013). Increase in forest water-use efficiency as atmospheric carbon dioxide concentrations rise. Nature, 499, 324-329. https://doi.org/10.1038/nature12291

Kharal, D. K., Thapa, U. K., St. George, S., Meilby, H., Rayamajhi, S., \& Bhuju, D. R. (2017). Tree-climate relations along an elevational transect in Manang Valley, central Nepal. Dendrochronologia, 41, 57-64. https://doi.org/10.1016/j.dendro.2016.04.004

Klein, T., Bader, M. K., Leuzinger, S., Mildner, M., Schleppi, P., Siegwolf, R. T., \& Korner, C. (2016). Growth and carbon relations of mature Picea 
abies trees under 5 years of free-air $\mathrm{CO}_{2}$ enrichment. Journal of Ecology, 104(6), 1720-1733. https://doi.org/10.1111/1365-2745.12621

Körner, C. (2007). The use of 'altitude' in ecological research. Trends in Ecology \& Evolution, 22(11), 569-574. https://doi.org/10.1016/ j.tree.2007.09.006

Körner, C. (2012). Alpine treelines: Functional ecology of the global high elevation tree limits. Basel, Switzerland: Springer.

Körner, C. (2015). Paradigm shift in plant growth control. Current Opinion in Plant Biology, 25, 107-114. https://doi.org/10.1016/ j.pbi.2015.05.003

Le Quéré, C., Andrew, R. M., Friedlingstein, P., Sitch, S., Hauck, J., Pongratz, J., ... Zheng, B. O. (2018). Global carbon budget 2018. Earth System Science Data, 10, 2141-2194. https://doi.org/10.5194/ essd-10-2141-2018

Lévesque, M., Siegwolf, R. T., Saurer, M., Eilmann, B., \& Rigling, A. (2014). Increased water-use efficiency does not lead to enhanced tree growth under xeric and mesic conditions. New Phytologist, 203(1), 94-109. https://doi.org/10.1111/nph.12772

Liang, E., Dawadi, B., Pederson, N., \& Eckstein, D. (2014). Is the growth of birch at the upper timberline in the Himalayas limited by moisture or by temperature? Ecology, 95(9), 2453-2465. https://doi. org/10.1890/13-1904.1

Liang, E., Leuschner, C., Dulamsuren, C., Wagner, B., \& Hauck, M. (2016). Global warming-related tree growth decline and mortality on the north-eastern Tibetan plateau. Climatic Change, 134(1), 163-176. https://doi.org/10.1007/s10584-015-1531-y

Linares, J. C., \& Camarero, J. J. (2012). From pattern to process: Linking intrinsic water-use efficiency to drought-induced forest decline. Global Change Biology, 18(3), 1000-1015. https://doi.org/ 10.1111/j.1365-2486.2011.02566.x

Lindner, M., Maroschek, M., Netherer, S., Kremer, A., Barbati, A., GarciaGonzalo, J., ... Marchetti, M. (2010). Climate change impacts, adaptive capacity, and vulnerability of European forest ecosystems. Forest Ecology and Management, 259(4), 698-709. https://doi.org/10.1016/ j.foreco.2009.09.023

Martínez-Sancho, E., Dorado-Liñán, I., Merino, E. G., Matiu, M., Helle, G., Heinrich, I., \& Menzel, A. (2018). Increased water-use efficiency translates into contrasting growth patterns of Scots pine and sessile oak at their southern distribution limits. Global Change Biology, 24, 1012-1028. https://doi.org/10.1111/gcb.13937

McCarroll, D., Gagen, M. H., Loader, N. J., Robertson, I., Anchukaitis, K. J., Los, S., ... Waterhouse, J. S. (2009). Correction of tree ring stable carbon isotope chronologies for changes in the carbon dioxide content of the atmosphere. Geochimica et Cosmochimica Acta, 73(6), 1539-1547. https://doi.org/10.1016/j.gca.2008.11.041

McCarroll, D., \& Loader, N. J. (2004). Stable isotopes in tree rings. Quaternary Science Reviews, 23(7), 771-801. https://doi.org/10.1016/ j.quascirev.2003.06.017

Miehe, S., Bäumler, R., Ghimire, S. K., Bhatrarai, K. R., Chaudhary, R. P., Subedi, M., ... Pendry, C. (2015). Vegetation ecology. In S. Miehe \& C. A. Pendry (Eds.), Nepal: An introduction to the natural history, ecology and human environment in the Himalayas (1st ed., pp. 385-472). Edinburgh, UK: Royal Botanical Garden Edinburgh.

Mountain Research Initiative EDW Working Group. (2015). Elevation dependent warming in mountain regions of the world. Nature Climate Change, 5(5), 424-430. https://doi.org/10.1038/NCLIM ATE2563

Myers, N., Mittermeier, R. A., Mittermeier, C. G., da Fonseca, G. A. B., \& Kent, J. (2000). Biodiversity hotspots for conservation priorities. Nature, 403(6772), 853-858. https://doi.org/10.1038/35002501

Nock, C. A., Baker, P. J., Wanek, W., Leis, A., Grabner, M., Bunyavejchewin, S., \& Hietz, P. (2011). Long-term increases in intrinsic water-use efficiency do not lead to increased stem growth in a tropical monsoon forest in western Thailand. Global Change Biology, 17(2), 1049-1063. https://doi.org/10.1111/j.1365-2486.2010.02222.x
Panthi, S. (2017). Long-term tree growths and their responses to global changes along elevation gradients in the central Himalaya and Hengduan Mountains. PhD dissertation. Xishuangbanna Tropical Botanical Garden, Chinese Academy of Sciences, Xishuangbanna, China.

Panthi, S., Bräuning, A., Zhou, Z.-K., \& Fan, Z.-X. (2017). Tree rings reveal recent intensified spring drought in the central Himalaya. Nepal. Global and Planetary Change, 57, 26-34. https://doi.org/10.1016/ j.gloplacha.2017.08.012

Panthi, S., Bräuning, A., Zhou, Z., \& Fan, Z.-X. (2018). Growth response of Abies georgei to climate increases with elevation in the central Hengduan Mountains, southwestern China. Dendrochronologia, 47, 1-9. https://doi.org/10.1016/j.dendro.2017.11.001

Paulsen, J., Weber, U. M., \& Korner, C. (2000). Tree growth near treeline: Abrupt or gradual reduction with altitude? Arctic, Antarctic, and Alpine Research, 32(1), 14-20. https://doi.org/10.2307/1552405

Peñuelas, J., Canadell, J. G., \& Ogaya, R. (2011). Increased water-use efficiency during the 20th century did not translate into enhanced tree growth. Global Ecology and Biogeography, 20(4), 597-608. https://doi. org/10.1111/j.1466-8238.2010.00608.x

Peters, R. L., Groenendijk, P., Vlam, M., \& Zuidema, P. A. (2015). Detecting long-term growth trends using tree rings: A critical evaluation of methods. Global Change Biology, 21, 2040-2054. https://doi. org/10.1111/gcb.12826

Peters, W., van der Velde, I. R., van Schaik, E., Miller, J. B., Ciais, P., Duarte, H. F., ... White, J. W. C. (2018). Increased water-use efficiency and reduced $\mathrm{CO}_{2}$ uptake by plants during droughts at a continental scale. Nature Geoscience, 11(10), 744-748. https://doi.org/10.1038/ s41561-018-0212-7

Qi, Z., Liu, H., Wu, X., \& Hao, Q. (2015). Climate-driven speedup of alpine treeline forest growth in the Tianshan Mountains, Northwestern China. Global Change Biology, 21, 816-826. https://doi.org/10.1111/ gcb.12703

R Core Team. (2018). R: A language and environment for statistical computing. Vienna, Austria: R Foundation for Statistical Computing. Retrieved from https://www.R-project.org/

Rahman, M., Islam, M., Gebrekirstos, A., \& Bräuning, A. (2019). Trends in tree growth and intrinsic water-use efficiency in the tropics under elevated $\mathrm{CO}_{2}$ and climate change. Trees, 33(3), 623-640. https://doi. org/10.1007/s00468-019-01836-3

Reed, C. C., Ballantyne, A. P., Cooper, L. A., \& Sala, A. (2018). Limited evidence for $\mathrm{CO}_{2}$-related growth enhancement in northern Rocky Mountain lodgepole pine populations across climate gradients. Global Change Biology, 24, 3922-3937. https://doi.org/10.1111/gcb.14165

Rinn, F. (2003). TSAP-win user reference manual. Heidelberg, Germany: Rinntech.

Salzer, M. W., Hughes, M. K., Bunn, A. G., \& Kipfmueller, K. F. (2009). Recent unprecedented tree-ring growth in bristlecone pine at the highest elevations and possible causes. Proceedings of the National Academy of Sciences of the United States of America, 106(48), 2034820353. https://doi.org/10.1073/pnas.0903029106

Sano, M., Ramesh, R., Sheshshayee, M. S., \& Sukumar, R. (2012). Increasing aridity over the past 223 years in the Nepal Himalaya inferred from a tree-ring $\delta^{18} \mathrm{O}$ chronology. The Holocene, 22(7), 809-817. https://doi. org/10.1177/0959683611430338

Sarris, D., Siegwolf, R., \& Körner, C. (2013). Inter- and intra-annual stable carbon and oxygen isotope signals in response to drought in Mediterranean pines. Agriculture and Forest Meteorology, 168, 59-68. https://doi.org/10.1016/j.agrformet.2012.08.007

Saurer, M., Spahni, R., Frank, D. C., Joos, F., Leuenberger, M., Loader, N. J., ... Young, G. H. F. (2014). Spatial variability and temporal trends in water-use efficiency of European forests. Global Change Biology, 20(12), 3700-3712. https://doi.org/10.1111/gcb.12717

Shrestha, K. B., Chhetri, P. K., \& Bista, R. (2017). Growth responses of Abies spectabilis to climate variations along an elevational gradient in Langtang National Park in the central Himalaya, Nepal. Journal of 
Forestry Research, 22(5), 274-281. https://doi.org/10.1080/13416 979.2017.1351508

Sigdel, S. R., Wang, Y., Camarero, J. J., Zhu, H., Liang, E., \& Penuelas, J. (2018). Moisture-mediated responsiveness of treeline shifts to global warming in the Himalayas. Global Change Biology, 24(11), 5549-5559. https://doi.org/10.1111/gcb.14428

Sigurdsson, B. D., Medhurst, J., Wallin, G., Eggertsson, O., \& Linder, S. (2013). Growth of mature boreal Norway spruce was not affected by elevated $\left[\mathrm{CO}_{2}\right]$ and/or air temperature unless nutrient availability was improved. Tree Physiology, 33(11), 1192-1205. https://doi. org/10.1093/treephys/tpt043

Silva, L. C. R., \& Anand, M. (2013). Probing for the influence of atmospheric $\mathrm{CO}_{2}$ and climate change on forest ecosystems across biomes. Global Ecology and Biogeography, 22, 83-92. https://doi. org/10.1111/j.1466-8238.2012.00783.x

Silva, L. C. R., Sun, G., Zhu-Barker, X., Liang, Q., Wu, N., \& Horwath, W. R. (2016). Tree growth acceleration and expansion of alpine forests: The synergistic effect of atmospheric and edaphic change. Science Advances, 2(8), e1501302. https://doi.org/10.1126/sciadv. 1501302

Steppe, K., Der Crone, J. S., \& De Pauw, D. J. (2016). TreeWatch.net: A water and carbon monitoring and modeling network to assess instant tree hydraulics and carbon status. Frontiers in Plant Science, 7, 993993. https://doi.org/10.3389/fpls.2016.00993

Stokes, M. A., \& Smiley, T. L. (1996). An introduction to tree-ring dating. Chicago, IL: Arizona University Press.

van der Schrier, G. V., Barichivich, J., Briffa, K. R., \& Jones, P. D. (2013). A scPDSI-based global data set of dry and wet spells for 1901-2009. Journal of Geophysical Research, 118(10), 4025-4048. https://doi. org/10.1002/jgrd.50355

van der Sleen, P., Groenendijk, P., Vlam, M., Anten, N. P., Boom, A., Bongers, F., ... Zuidema, P. A. (2015). No growth stimulation of tropical trees by 150 years of $\mathrm{CO}_{2}$ fertilization but water-use efficiency increased. Nature Geoscience, 8(1), 24-28. https://doi.org/10.1038/ NGEO2313

Wieloch, T., Helle, G., Heinrich, I., Voigt, M., \& Schyma, P. (2011). A novel device for batch-wise isolation of $\alpha$-cellulose from small-amount wholewood samples. Dendrochronologia, 29(2), 115-117. https://doi. org/10.1016/j.dendro.2010.08.008

Xu, C., Sano, M., Dimri, A. P., Ramesh, R., Nakatsuka, T., Shi, F., \& Guo, Z. (2018). Decreasing Indian summer monsoon in northern Indian subcontinent during the last 180 years: Evidence from five tree cellulose oxygen isotope chronologies. Climate of the Past, 14, 653-664. https ://doi.org/10.5194/cp-14-653-2018

Zuidema, P. A., Baker, P. J., Groenendijk, P., Schippers, P., van der Sleen, P., Vlam, M., \& Sterck, F. (2013). Tropical forests and global change: Filling knowledge gaps. Trends in Plant Science, 18, 413-419. https:// doi.org/10.1016/j.tplants.2013.05.006

Zuidema, P. A., Poulter, B., \& Frank, D. (2018). A wood biology agenda to support global vegetation modelling. Trends in Plant Science, 23(11), 1006-1015. https://doi.org/10.1016/j.tplants.2018.08.003

\section{SUPPORTING INFORMATION}

Additional supporting information may be found online in the Supporting Information section.

How to cite this article: Panthi S, Fan Z-X, van der Sleen P, Zuidema PA. Long-term physiological and growth responses of Himalayan fir to environmental change are mediated by mean climate. Glob Change Biol. 2019;00:1-17. https://doi. org/10.1111/gcb.14910 